\title{
Angiotensin II Effects upon the Glomerular Microcirculation and Ultrafiltration Coefficient of the Rat
}

\author{
Roland C. Blantz, Karen S. Konnen, and Bryan J. Tucker \\ From the Departments of Medicine, University of California, San Diego, \\ School of Medicine, and Veterans Administration Hospital, \\ San Diego, California 92161
}

A B S T R A C T The effects of both synthetic and biologically produced angiotensin II (AII) upon the process of glomerular filtration were examined in the plasma-expanded (2.5\% body wt) Munich-Wistar rat, by micropuncture evaluation of pressures, nephron plasma flow (rpf) and filtration rate (sngfr). Plasma expansion was chosen as a control condition because (a) response to AII was uniform and predictable, (b) endogenous generation of AII was presumably suppressed, and $(c)$ the high control values for rpf permitted accurate determination of values for the glomerular permeability coefficient ( $\left.L_{p} A\right)$ before and during AII infusion. With subpressor quantities of synthetic Asn-1, Val-5 AII ( $<5 \mathrm{ng} / 100 \mathrm{~g}$ body wt $/ \mathrm{min}$ ), sngfr fell from 47.7 in the control group to $39.8 \mathrm{nl} / \mathrm{min} / \mathrm{g}$ kidney $(P<$ $0.005)$. The rpf fell to $60 \%$ of control values $(P<$ $0.001)$. Measurement of glomerular capillary $\left(P_{a}\right)$ and Bowman's space $\left(P_{t}\right)$ hydrostatic pressures in surface glomeruli with a servo-nulling device permitted evaluation of the hydrostatic pressure gradient $\left(\Delta P=P_{G}-\right.$ $\left.P_{t}\right) . \Delta P$ increased from $38.1 \pm 1.2$ in control to $45.9 \pm 1.3$ $\mathrm{mm} \mathrm{Hg}$ after Asn-1, Val-5 AII and essentially neutralized the effect of decreased rpf in sngfr. The sngfr then fell as a result of a decrease in $L_{p} A$ from $0.063 \pm 0.008$ in control to $0.028 \pm 0.004 \mathrm{nl} / \mathrm{s} / \mathrm{g}$ kidney $/ \mathrm{mm} \mathrm{Hg}$ after Asn-1, Val-5 AII $(P<0.02)$.

Lower doses of Asp-1, Ile-5 AII ( $<3 \mathrm{ng} / 100 \mathrm{~g}$ body $\mathrm{wt} / \mathrm{min}$ ) had no effect on sngfr, rpf, $\Delta P$, and afferent and efferent vascular resistance, but significantly elevated systemic blood pressure, suggesting peripheral ef-

Portions of this study were presented at the annual meeting of the American Federation for Clinical Restearch, Atlantic City, N. J., 4 May 1975.

Dr. Blantz is presently a Clinical Investigator of the Veterans Administration.

Received for publication 16 April 1975 and in revised form 3 October 1975. fects on smooth muscle at this low dose. $L_{p} A$ was $0.044 \pm$ $0.007 \mathrm{nl} / \mathrm{s} / \mathrm{g}$ kidney $/ \mathrm{mm} \mathrm{Hg}$ after low-dose Asp-1, Ile-5 AII, and $0.063 \pm 0.008$ in the control group $(0.2>P>$ 0.1 ). Higher, equally pressor doses of native AII ( $5 \mathrm{ng} /$ $100 \mathrm{~g}$ body $\mathrm{wt} / \mathrm{min}$ ) produced effects almost identical to similar quantites of synthetic Asn-1, Val-5 AII upon rpf, $\Delta P$, sngfr, and renal vascular resistance. $L_{p} A$ again fell to $0.026 \pm 0.004 \mathrm{nl} / \mathrm{s} / \mathrm{g}$ kidney $/ \mathrm{mm} \mathrm{Hg}$, a value almost identical to that after the synthetic AII. Paired studies with Asp-1, Ile-5 AII also demonstrated a consistent reduction in $\mathrm{L}_{\mathrm{p}} \mathrm{A}$.

Both synthetic (Asn-1, Val-5 AII) and native AII (Asp-1, Ile-5 AII) produce a reduction in $\mathrm{L}_{p} A$, presumably by direct action on the glomerular capillary or mesangium, where no smooth muscle cells are present. Although quantitative differences in peripheral vascular effects of the two forms of AII are demonstrated, the effects on $L_{p} A$ occur at similar doses of both agents in the plasma-expanded rat. A third major physiologic action for AII is postulated that requires an effector cell in the glomerulus that differs from those previously demonstrated for vascular smooth muscle and the adrenal glomerulosa.

\section{INTRODUCTION}

Angiotensin II (AII) ${ }^{1}$ has been demonstrated to be the most potent biologically produced vasoconstrictor (1-3).

\footnotetext{
${ }^{1}$ Abbreviations used in this paper: $A$, glomerular capillary surface area; $\Lambda$, afferent arteriolar; AII, angiotensin II; $\mathrm{AR}$, afferent arteriolar resistance $\left(10^{\circ} \mathrm{dyn} \cdot \mathrm{s} \cdot \mathrm{cm}^{-5}\right) ; C_{\Lambda}$, systemic protein concentration $(\mathrm{g} / 100 \mathrm{ml}) ; C_{\boldsymbol{B}}$, efferent peritubular capillary protein concentration $(\mathrm{g} / 100 \mathrm{ml})$; EFP, effective filtration pressure $(\mathrm{mm} \mathrm{Hg}) ; s$, systemic or efferent arteriolar; ER, efferent arteriolar resistance $\left(10^{\circ} \mathrm{dyn} \cdot \mathrm{s} \cdot \mathrm{cm}^{-5}\right)$; FF, kidney filtration fraction (GFR/ $\mathrm{RPF})$; GFR, glomerular filtration rate $(\mathrm{ml} / \mathrm{min} / \mathrm{g}$ kidney);
} 
Studies have demonstrated that the polypeptide acts on smooth muscle to increase vascular resistance in both the peripheral and renal circulation (4-6). Physiologic studies have suggested that AII acts upon smooth muscle of both the afferent, precapillary arteriole and the postcapillary, efferent arteriole $(5,6)$. AII has also been shown to release aldosterone from the adrenal cortex (7), and recent studies have suggested that this action of AII may be mediated through an entirely different receptor cell for AII (8). Therefore, the biologic activity of AII, has been well defined for both vascular smooth muscle and the adrenal cortex in prior studies.

Hornych et al. have recently demonstrated that both pressor and subpressor quantities of Asn-1, Val-5 AII produced significant constriction of glomerular capillaries of the rat, as evaluated by scanning microscopy (9). Also, investigations by Sraer et al., utilizing isolated glomeruli, have shown a reduction in glomerular diameter when glomeruli were suspended in solutions containing Asn-1, Val-5 AII (10). These studies suggest an action for AII on the glomerular capillary, a portion of the vasculature that does not possess smooth muscle.

Although the potential AII effect on the glomerular capillary may not contribute significantly to the overall effect of AII upon renal vascular resistance, a reduction in capillary radius should be associated with a proportional decrease in glomerular capillary surface area $(A)$.

The purposes of the present study are to: $(a)$ determine whether low doses of Asn-1, Val-5 AII provides a reduction in the glomerular permeability coefficient $\left(\mathrm{L}_{\mathrm{p}} \mathrm{A}\right)$, either through decreases in filtering surface area $(A)$ or through reduction in local capillary permeability ( $\left.L_{p}\right)(11,12)$; $(b)$ determine if the AII produced endogenously by the rat (Asp-1, Ile-5 AII) (13) has effects similar to those of Asn-1, Val-5 AII ; and (c) define the relative effects of both forms of AII upon peripheral vascular resistance and the glomerular permeability coefficient.

\section{METHODS}

Experiments were performed on male Munich-Wistar rats (160-240 g), bred and housed at the animal facility at the

hct, hematocrit $(\%) ; l$, capillary length; $\mathrm{L}_{\mathbf{p}}$, local capillary permeability; $\mathrm{L}_{\mathrm{p}} \mathrm{A}$, total glomerular permeability (nl/s/g kidney $/ \mathrm{mm} \mathrm{Hg}$ ) ; MAP, mean arterial blood pressure (mm $\mathrm{Hg}) ; \Delta P$, hydrostatic pressure gradient between glomerular capillary and Bowman's space $(\mathrm{mm} \mathrm{Hg}) ; P_{G}$, glomerular capillary hydrostatic pressure $(\mathrm{mm} \mathrm{Hg}) ; P_{t}$, Bowman's space or proximal tubule hydrostatic pressure $(\mathrm{mm} \mathrm{Hg})$; $\pi$, oncotic pressure $(\mathrm{mm} \mathrm{Hg})$; rbf, nephron blood flow (nl/ $\mathrm{min} / \mathrm{g}$ kidney); rpf, nephron plasma flow ( $\mathrm{nl} / \mathrm{min} / \mathrm{g}$ kidney); RPF, kidney plasma flow ( $\mathrm{ml} / \mathrm{min} / \mathrm{g}$ kidney); snff, nephron filtration fraction (sngfr/rpf); sngfr, superficial nephron filtration rate $(\mathrm{nl} / \mathrm{min} / \mathrm{g}$ kidney $) ; x^{*}$, glomerular capillary length.
San Diego Veterans Administration Hospital, La Jolla, Calif. Rats were fed regular chow (Ralston Purina Co., St. Louis, Mo.) until approximately $16 \mathrm{~h}$ before micropuncture surgery, and permitted free access to water. Animals were anesthetized with Inactin $(100 \mathrm{mg} / \mathrm{kg}$ body wt, i.p., Promonta, Hamburg, W. Germany) and a tracheostomy (P.E. 240) was immediately performed, followed by catheter (P.E. 50) placement in left jugular vein, left femoral artery, and bladder. The rat was then turned onto the right side on a servo-controlled, heated animal table, a left subcostal incision was made, and the kidney was exposed, placed into a Lucite cup, and lined as previously described (11, 12, 14). A ureteral catheter (P.E. 50) about $3 \mathrm{~cm}$ long was utilized to collect urine from the left kidney. Surgical losses were not replaced but an infusion of isotonic $\mathrm{NaCl}-\mathrm{NaHCO}_{3}$ was maintained at $0.5 \%$ body $\mathrm{wt} / \mathrm{h}$ until volume expansion was undertaken.

On the morning of the study a litter mate was sacrificed as a plasma donor. All rats were infused with $2.5 \%$ (body $\mathrm{wt}$ ) of donor plasma over a total of $60 \mathrm{~min}$. At this time, an infusion of $\left[{ }^{14} \mathrm{C}\right]$ inulin $(\sim 40 \mu \mathrm{Ci} / \mathrm{ml})$ was infused continuously at $0.5 \%$ body $\mathrm{wt} / \mathrm{h}$. At the end of this infusion, urine flow rate was measured and an infusion of isotonic $\mathrm{NaCl}-\mathrm{NaHCO}_{3}$ was begun to equal this volume flow rate to maintain both the degree of volume expansion and a constant systemic protein concentration during all measurements.

Two general types of studies were performed: a large number of unpaired studies in four groups after plasma volume expansion; ( $a$ ) control, (b) subpressor doses of Asn-1,Val-5 AII, (c) low-dose rat Asp-1,Ile-5 AII, and (d) high-dose AII ; and paired studies in which endogenous rat AII was infused after measurements in a control plasmaexpanded condition. The unpaired studies were found preferable because the degree of expansion and time after expansion was uniform at the time of AII infusion. With time and lesser degrees of expansion, intrarenal AII generation may increase the variability of response and increase the variance of observations. The paired studies were performed to confirm the effects of AII on the filtration process. After volume expansion in unpaired group studies, angiotensin infusion was begun and the rate rapidly increased to the stable, desired value while systemic blood pressure was constantly monitored. A separate intravenous infusion rate was again adjusted to urine output after a stable, constant angiotensin infusion was established. Since approximately $10-15 \mathrm{~min}$ were required to achieve the desired angiotensin infusion rate, a similar period of time was allowed in control plasma expansion before initial measurements.

Experimental groups. Studies were performed on four groups of animals, all of which were expanded with isoncotic plasma $(2.5 \%$ body $w t)$. Prior volume expansion elevates nephron plasma flow to more than twice the normal hydropenic value and thereby disequilibrates the effective filtration pressure, and a positive value persists at the efferent end of the glomerular capillary (15). This condition permits calculation of an accurate and unique value for the glomerular permeability coefficient $\left(\mathrm{L}_{\mathrm{p}} \mathrm{A}\right)(11,12)$. If filtration pressure equilibrium persists, as in the normal hydropenic rat, only a minimum possible value for $\mathrm{L}_{\mathrm{p}} \mathrm{A}$ may be defined $(11,12,14)$. The control group $(n=11)$ consisted of plasma-expanded rats. The second group $(n=$ $6)$ consisted of similarly expanded rats during the infusion of subpressor quantities ( $<10 \mathrm{~mm} \mathrm{Hg}$ increase) of Asn-1, Val-5 AII (Ciba Pharmaceutical Company, Summit, N. J.) $(<5 \mathrm{ng} / 100 \mathrm{~g}$ body $\mathrm{wt} / \mathrm{min})$. The third group of rats 
$(n=5)$ was also plasma expanded and studied during low-dose infusions of Asp-1, Ile-5 AII $(<3 \mathrm{ng} / 100 \mathrm{~g}$ body wt $/ \mathrm{min}$ ), the form of AII produced endogenously by the rat (13). In this group, the infusion rate of Asn-1, Val-5 AII could not be duplicated without significant systemic hypertension. In fact, increases in blood pressure occurred consistently with an infusion rate as low as 1-2 $\mathrm{ng} / 100 \mathrm{~g}$ body $\mathrm{wt} / \mathrm{min}$. The relative potency of the endogenous AII and the synthesized AII (Asn-1, Val-5 AII) was quite similar to that previously reported (16). The last group $(n=6)$ involved a duplication of the Asn-1, Val-5 AII infusion rate with the endogenously produced AII (Asp-1, Ile-5 AII), again upon the background of isoncotic plasma expansion. At infusion rates of $>5 \mathrm{ng} / 100 \mathrm{~g}$ body $\mathrm{wt} / \mathrm{min}$, the effects were uniformly hypertensive in the expanded rat.

Paired studies. In these studies the rats were expanded as in other groups and all measurements obtained. At the end of the control period, an infusion of Asp-1, Ile-5 AII was begun to produce an elevation of systemic blood pressure of at least $25 \mathrm{~mm} \mathrm{Hg}$. The infusion rate was then continued at this level. A period of $15 \mathrm{~min}$ then elapsed at a stable, elevated blood pressure before experimental measurements were begun. All micropuncture and clearance measurements were then repeated during this stable AII infusion.

Micropuncture measurements. After stabilization of urine flow and intravenous infusion rate in each group, several measurements were obtained in each animal over a maximum of 80-90 min. Pressures were measured in all accessible glomerular capillaries and the accompanying Bowman's space with a servo-nulling device with $1-\mu \mathrm{m}$-tip pipettes. Pressures were also measured in several proximal tubules and in a set of "star" efferent peritubular capillaries. The specific operation of this device and the procedures and criteria required for adequate pressure measurements in glomerular capillaries have been explained in detail in previous publications from this laboratory $(11,12,17)$. We should reiterate, however, that if bleeding occurred into either Bowman's space or upon the surface, the pressure was discarded and not utilized. At least three efferent peritubular capillary blood samples were obtained from star vessels in each rat. Samples were of sufficient volume to provide at least three $7-n l$ samples of plasma for analysis of protein concentration. Samples of systemic (femoral artery) blood were obtained concurrently for protein analysis.

A set of four to six nephron filtration rates were obtained in each animal. An 8-11- $\mu$ m-tip glass pipette was carefully inserted into late proximal tubular segments and a mineral oil block of at least 3-4 tubular diameters was injected and, after initial gentle aspiration, tubular fluid entered the pipette. Collections were usually spontaneous throughout the time period. Care was taken to prevent alterations in tubular diameter during the entire period of tubular fluid collection.

During the entire period of measurements, the total urine volume was collected in preweighed containers under oil and from the radioactivity in both urine and plasma samples, the total kidney glomerular filtration rate (GFR) was determined $(11,12,14)$. Usually, two separate collection periods were obtained from both right and left kidneys. At the end of the measurements, a renal vein blood sample was obtained with a heparinized $25-35-\mu \mathrm{m}$-tip glass pipette to determine the rate of total renal plasma flow from the extraction of $\left[{ }^{14} \mathrm{C}\right]$ inulin. After completion of each study, the left kidney was removed and weighed.

In paired studies, the complete sequence of measurements was performed both during the control period and during the AII infusion.

Analytical methods. Nephron filtration rate was calculated from the total counts of $\left[{ }^{14} \mathrm{C}\right]$ inulin in the tubular fluid sample divided by the plasma counts per nanoliter and the time of collection. Total GFR kidney plasma flow and filtration fraction were calculated as previously described $(11,12,14)$.

After collection of efferent peritubular blood samples, the tips were sealed with several coats of Eastman 910 (Eastman Kodak Co., Rochester, N. Y.) and the cells separated from plasma by centrifugation. At least three 7-nl samples were obtained from each collection with a constant-volume quartz pipette. Protein concentration was determined from a micro-adaptation of the Lowry protein method (18), as described in prior communications from this laboratory $(12,14)$. Each sample was read in triplicate and therefore the efferent peritubular protein concentrations were usually determined from nine readings.

Plasma and urine electrolytes were determined on a flame photometer (Instrumentation Laboratory, Inc., Lexington, Mass.). Osmolality was measured with either an Advanced Instruments osmometer (Advanced Instruments, Inc., Needham Heights, Mass.) or a nanoliter osmometer (Clifton Technical Physics, Hartford, N. Y.) if samples were small. Urine protein concentration was determined by the sulfasalicylic acid method (19). Plasma electrophoreses were performed on cellulose acetate strips and read on an automatic reading densitometer. The percentage of total serum protein that was albumin and globulin was determined from electrophoretic patterns by planimetry (11).

Calculations. The nephron plasma flow (rpf) is calculated as follows:

$$
\mathrm{rpf}=\mathrm{sngfr} /\left(1-C_{\Delta} / C_{B}\right)
$$

where $C_{A}$ is the systemic protein concentration, $C_{B}$ is the efferent peritubular capillary protein concentration determined by microprotein methods, and $\left(1-C_{A} / C_{B}\right)=$ the nephron filtration fraction (snff $=$ sngfr $/$ rpf). Nephron blood flow (rbf) was determined from the following relationship :

$$
\mathrm{rbf}=\mathrm{rpf} /(1-\mathrm{hct})
$$

where hct is the hematocrit expressed as a fraction of one. Afferent arteriolar resistance (AR) is defined as follows:

$$
\mathrm{AR}=\left(\mathrm{MAP}-\mathrm{P}_{\boldsymbol{\theta}}\right) / \mathrm{rbf}
$$

where MAP is mean systemic blood pressure and $P_{G}$ is glomerular capillary hydrostatic pressure, both in millimeters of mercury. Efferent arteriolar resistance (ER) is defined by the similar relationship:

$$
\mathrm{ER}=\left(P_{G}-\mathrm{HP}_{\boldsymbol{B}}\right) /(\text { rbf-sngfr })
$$

where $\mathrm{HP}_{E}$ is large efferent peritubular capillary hydrostatic pressure.

The measured $P_{G}$ in any state is assumed to represent the mean value or that value at the midpoint of the capillary length. In previous studies in hydropenic rats, utilizing repeated measurements of $P_{G}$ in the same glomerulus during hydropenia, we have found that the range of values does not exceed $2 \mathrm{~mm} \mathrm{Hg}$. Since this value is also influenced by both the accuracy of the servo-nulling device and error in reading of pressures, the decrease in $P_{G}$ along capillary length $\left(\Delta P_{G}\right)$ is probably $1 \mathrm{~mm} \mathrm{Hg}$ or less, but certainly less than $2 \mathrm{~mm} \mathrm{Hg}$. It is assumed that this is also true for plasma volume expansion. All resistances are expressed in dyn $\cdot \mathrm{s} \cdot \mathrm{cm}^{5}$. 
Total renal plasma flow and renal blood flow were determined as previously described.

The determinants of sngfr are defined as follows:

$$
\text { sngfr }=\mathrm{L}_{\mathrm{p}} \mathrm{A} \cdot \overline{\mathrm{EFP}}
$$

where mean effective filtration pressure $=\overline{\mathrm{EFP}}$. EFP along the glomerular capillary length $\left(x^{*}\right)$ (where $x^{*}=x / l$ and $l=$ capillary length) is described as follows:

$$
\operatorname{EFP}_{x *}=(\Delta P-\pi)_{x *}
$$

where $\pi=$ oncotic pressure $(\mathrm{mm} \mathrm{Hg})$ which is related to $\mathrm{C}(\mathrm{g} / 100 \mathrm{ml})$ as follows :

$$
\pi=1.76 C+0.28 C^{2}(11,12,14)
$$

a simplification of the empirical relationship described by Landis and Pappenheimer (20).

$$
\pi=2.1 C+0.16 C^{2}+0.009 C^{3}
$$

The $\overline{\mathrm{EFP}}$ is defined as follows:

$$
\overline{\mathrm{EFP}}=\int_{0}^{1}(\Delta P-\pi) d x^{*}
$$

The $\operatorname{EFP}_{x} *$ curve and $\mathrm{L}_{\mathrm{p}} \mathrm{A}$ are determined by an iterative method as described previously from this laboratory (12).

Statistical methods. All input variables were submitted to analysis of variance (21) and variance estimates of all variables were carried through the calculation of $\overline{\mathrm{EFP}}$, generation of the $\mathrm{EFP}_{x *}$ profile, and $\mathrm{L}_{\mathrm{p}} \mathrm{A}$ to define the final estimate of variance of these values (12). The values for $\mathrm{L}_{\mathrm{p}} \mathrm{A}$ after Asn-1, Val-5 AII and high-dose Asp-1, Ile-5 AII were applied to both the normal hydropenic values for $\Delta \mathrm{P}, \mathrm{rpf}$, and $C_{A}$ and the predicted changes in these values after AII, based upon percentage changes observed in the plasma volume expanded condition. Also, the $L_{p} A$ value in the control conditions was applied to the post-AII condition (with AII values for $\Delta P$, rpf, and $C_{A}$ ) to predict the $\mathrm{EFP}_{x *}$ profile if $L_{p} A$ had not been altered by AII (Fig. 3).

\section{RESULTS}

Group data. The data obtained in the three experimental groups will be compared to the control plasma volume expansion ( $2.5 \%$ body $w t)$ with no infusion of AII. As stated, all animals were expanded identically and total intravenous infusion rates were adjusted to equal spontaneous urine output.

Effects of Asn-1, Val-5 AII infusion ( $<5 \mathrm{ng} / 100 \mathrm{~g}$ body $w t / \mathrm{min}$ ). In no case did blood pressure (MAP) increase by more than $10 \mathrm{~mm} \mathrm{Hg}(122 \pm 3$ versus $133 \pm 6$, $P>0.05$ after AII). The AII infusion rate was established at the first sign of an elevation in MAP. The sngfr was $47.7 \pm 1.4 \mathrm{nl} / \mathrm{min} \mathrm{g}$ kidney $(n=50)$ in the control plasma expansion group, and in the experimental group was significantly lower during Asn-1, Val-5 AII infusion at $39.8 \pm 2.2 \mathrm{nl} / \mathrm{min} / \mathrm{g}$ kidney $(n=29) \quad(P<$ 0.005 ) (Figs. 1 and 2). The nephron plasma flow (rpf) was also significantly lower during AII infusion, at $119 \pm 7 \mathrm{nl} / \mathrm{min} / \mathrm{g}$ kidney, compared to $200 \pm 9$ in the control group $(P<0.001)$ (Fig. 1). rbf fell from $346 \pm$ 16 to $214 \pm 12 \mathrm{nl} / \mathrm{min} / \mathrm{g}$ kidney $(P<0.001)$.
Data were also analyzed by animal mean values: the sngfr was $47.3 \pm 2.4(n=11)$ in control rats and 39.6 \pm $4.0(n=6) \mathrm{nl} / \mathrm{min} / \mathrm{g}$ kidney $(0.1>P>0.05)$ after Asn-1, Val-5 AII, the rpf was $198 \pm 18$ in controls and $119 \pm 14 \mathrm{nl} / \mathrm{min} / \mathrm{g}$ kidney $(P<0.005)$ after AII, and the rbf was $344 \pm 32$ in control rats and $213 \pm 25 \mathrm{nl} /$ $\mathrm{min} / \mathrm{g}$ kidney $(P<0.01)$ after AII. This reduction in rbf was the result of an increase in both afferent (AR) and efferent arteriolar resistance (ER). AR rose to $26 \pm 3 \times 10^{8}$ dyn $\mathrm{s} \mathrm{cm}^{-5}$ with AII, compared to $17 \pm 2 \times$ $10^{\circ}$ dyn s cm $\mathrm{cm}^{-6}$ in the control state $(P>0.02)$. The increase in ER was more impressive at $10 \pm 1 \times 10^{\circ}$ dyn $\mathrm{s}$ $\mathrm{cm}^{-5}$ in control rats and $23 \pm 3 \times 10^{\circ}$ during Asn-1, Val-5 AII infusion $(P<0.001)$. Although the control conditions differed, the respective changes in AR and ER were quite similar to those reported for the hydropenic $\mathrm{Mu}$ nich-Wistar rat in a recent abstract by Deen et al. (22).

The $P_{a}$ rose with AII, presumably as a result of the greater increase in ER. Control $P_{G}$ was $59.5 \pm 1.5 \mathrm{~mm} \mathrm{Hg}$ and $64.0 \pm 0.8 \mathrm{~mm} \mathrm{Hg}$ during AII infusion $(P<0.02)$. In contrast to other conditions in which $P_{a}$ rises $(11,14$, $16)$, the proximal tubule hydrostatic pressure $\left(P_{t}\right)$ fell with AII infusion from $20.3 \pm 0.7$ in control to $18.4 \pm$ $0.6 \mathrm{~mm} \mathrm{Hg}(P<0.05)$. The net effect of the divergent changes in $P_{a}$ and $P_{t}$ was a rather dramatic increase in hydrostatic pressure gradient between glomerular capillary and Bowman's space $(\Delta P)$ from a control group value of $38.1 \pm 1.2 \mathrm{~mm} \mathrm{Hg}(n=25)$ to $45.9 \pm 1.3(n=$ 12) during AII infusion $(P<0.001)$ (Fig. 1). When changes were analyzed from mean values for each animal, $\Delta P$ increased from $37.9 \pm 1.3$ in control rats to $45.4 \pm$ $1.4 \mathrm{~mm} \mathrm{Hg}(P<0.005)$ after Asn-1, Val-5 AII. The large efferent peritubular capillary hydrostatic pressure $\left(\mathrm{HP}_{\mathrm{s}}\right.$ ) fell from $22.9 \pm 1.2 \mathrm{~mm} \mathrm{Hg}$ in the control group to $17.8 \pm 1.0$ during AII infusion $(P<0.005)$. Data for each animal in this group are summarized in Table $I$.

Total kidney GFR was $1.50 \pm 0.20 \mathrm{ml} / \mathrm{min} / \mathrm{g}$ kidney in the control group $(n=6)$ and $1.10 \pm 0.08$ during AII infusion $(0.2>P>0.1)$. Renal plasma flow was $3.15 \pm$ $0.7 \mathrm{ml} / \mathrm{min} / \mathrm{g}$ kidney and renal blood flow $5.7 \pm 1.2 \mathrm{ml} /$ $\mathrm{min} / \mathrm{g}$ kidney $(n=5)$ in this group. Total filtration fraction was $0.38 \pm 0.04$, very similar to the snff $(0.34 \pm 0.03)$.

The appearance of the kidney surface was not greatly altered by the infusion of Asn-1, Val-5 AII. The only consistent changes were a slight diminution in tubular diameter accompanied by an appearance of increasing "thickness" of tubular cells or wall opacity and some decrease in the "tightness" of the renal capsule. The general color and relationship of tubular and vascular structures were not changed by AII infusion.

The systemic oncotic pressure was somewhat lower in this AII group, at $15.7 \pm 0.9 \mathrm{~mm} \mathrm{Hg}$ as compared to $18.4 \pm 0.5$ in control rats $(P<0.02)$, but was not different in the other AII experimental groups. The he- 
matocrit did not change from control $(42 \pm 1)$ at $44 \pm 2$ $(P>0.10)$. Systemic oncotic pressure rose to a value at the end of the capillary $\left(\pi_{B}\right)$ of $29.4 \pm 1.7 \mathrm{~mm} \mathrm{Hg}$ in this group and $28.4 \pm 0.8 \mathrm{~mm} \mathrm{Hg}$ in the control condition $(P>0.5)$. The snff was therefore $0.25 \pm 0.02$ in the control condition, but significantly higher during the AII infusion at $0.34 \pm 0.03(P<0.02)$. As a result of the high control rpf, the EFP at the end of the glomerular capillary $\left(\mathrm{EFP}_{s}=\Delta \mathrm{P}-\pi_{s}\right)$ was greater than 0 at $9.5 \pm 1.7$ $\mathrm{mm} \mathrm{Hg}$. During AII infusion the mean $\mathrm{EFP}_{s}$ was higher at $16.0 \pm 1.3 \mathrm{~mm} \mathrm{Hg}(P<0.001)$ in spite of the large reduction in rpf with AII. The only other factor which could have further disequilibrated the EFP while rpf fell was a large reduction in $L_{p} A(14,16 a)$. The effect of the reduction in rpf upon sngfr was effectively neutralized by the large rise in $\Delta P$. Therefore, the fall in sngfr observed must primarily result from a decrease in $L_{p} A$. The profile of $\mathrm{EFP}_{x^{*}}$ was generated for the control condition and during Asn-1, Val-5 AII infusion. The $\overline{\text { EFP }}$ in the control group was $14.5 \pm 1.6 \mathrm{~mm} \mathrm{Hg}$ and was significantly higher during AII infusion, at $23.5 \pm 0.8 \mathrm{~mm}$ $\mathrm{Hg}(P<0.005)$. Since sngfr fell while $\overline{\mathrm{EFP}}$ rose, the $L_{p} A$ must have decreased with Asn-1, Val-5 AII in subpressor quantities. $\mathrm{L}_{\mathrm{p}} \mathrm{A}$ in the control group was $0.063 \pm$ $0.008 \mathrm{nl} / \mathrm{s} / \mathrm{g}$ kidney $\mathrm{mm} \mathrm{Hg}(n=11)$ and was signifi-
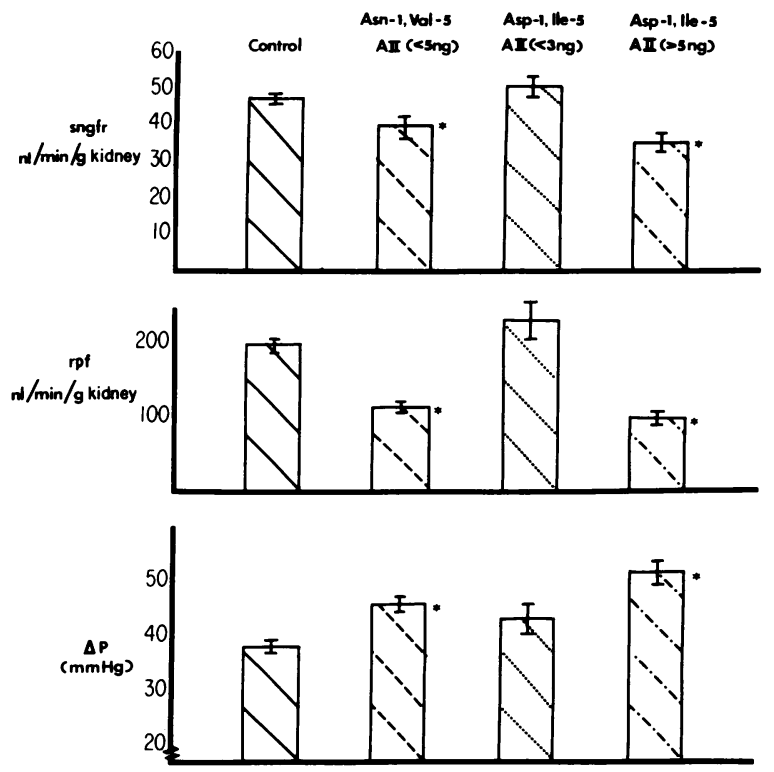

Figure 1 The effect of Asn-1, Val-5 AII ( $\leqslant 5 \mathrm{ng} / 100 \mathrm{~g}$ body $\mathrm{wt} / \mathrm{min}$ ) and Asp-1, Ile-5 AII ( $<3 \mathrm{ng}$ and $\geqslant 5 \mathrm{ng} /$ $100 \mathrm{~g}$ body $\mathrm{wt} / \mathrm{min}$ ) upon nephron filtration rate (sngfr), nephron plasma flow (rpf), and the glomerular capillary hydrostatic pressure gradient $\left(\Delta P=P_{G}-P_{t}\right)$. Each vertical bar delineates the mean values \pm SEM for, from the left, control group, Asn-1, Val-5 AII, low-dose Asp-1, Ile-5 AII, and high-dose Asp-1, Ile-5 AII. The asterisk signifies values different from the control group $(P<0.005)$.
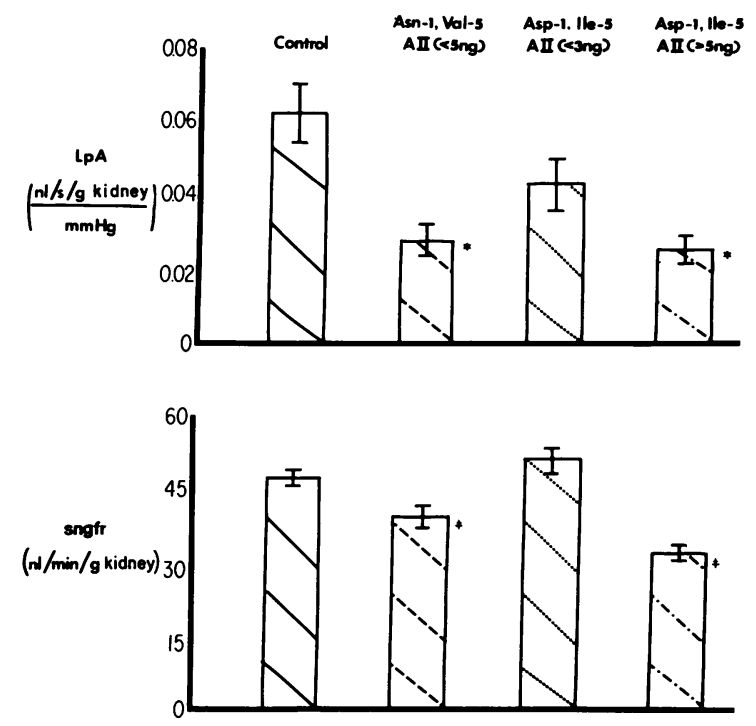

Figure 2 The effect of Asn-1, Val-5 AII ( $\leqslant 5 \mathrm{ng} / 100 \mathrm{~g}$ body wt/min) and Asp-1, Ile-5 AII upon the glomerular permeability coefficient $\left(\mathrm{L}_{\mathrm{p}} \mathrm{A}\right)$ and the nephron filtration rate (sngfr). Each vertical bar delineates the mean values \pm SEM for each group. In both Asn-1, Val-5 AII ( $\leqslant 5$ $\mathrm{ng}$ ) and Asp-1, Ile-5 AII ( $\geqslant 5 \mathrm{ng}$ ) group, the $\mathrm{L}_{\mathrm{p}} \mathrm{A}$ and sngfr were both significantly reduced from the control group. There was no difference in either $\mathrm{L}_{\mathrm{p}} \mathrm{A}$ or sngfr with Asp-1, Ile-5 AII ( $<3 \mathrm{ng} / 100 \mathrm{~g}$ body $\mathrm{wt} / \mathrm{min}$ ).

cantly lower in this AII group at $0.028 \pm 0.004 \mathrm{nl} / \mathrm{s} / \mathrm{g}$ kidney $\mathrm{mm} \mathrm{Hg}(n=6)(P<0.02)$ (Fig. 2$)$.

If $L_{p} A$ had remained equal to control values after Asn-1, Val-5 AII, the sngfr would not have changed from control values. Also, the profile of EFP* would have differed and $\overline{\mathrm{EFP}}$ remained relatively constant, equal to the control value. In Fig. 3 , the observed profile of EFP along $x^{*}$ during AII is shown, along with the EFP profile which would obtain if $L_{p} A$ had remained equal to the value in control animals. The figure demonstrates that the reduction in $\mathrm{L}_{p} \mathrm{~A}$ alters the profile of $\mathrm{EFP}_{x *}$ and increases $\overline{\mathrm{EFP}}$ by reducing the rate of ultrafiltration along $x^{*}$ and decreasing the rate of rise in $\pi$ along the capillary.

All of the effects in this group occurred before evidence of significant increases in peripheral resistance, as indicated by no change in MAP. The AII effects were the result of infusion of a form of the peptide not produced biologically in any species (23). Although the qualitative effects of Asn-1, Val-5 AII have been reported identical to endogenously produced AII $(24,25)$, it remains possible that these results were unique to this synthetic form of AII. For these reasons, studies were performed with Asp-1, Ile-5 AII, the form of AII produced by the rat (13).

Effects of low-dose Asp-1, Ile-5 AII ( $<3 \mathrm{ng} / 100 \mathrm{~g}$ body wt/min). Initially, we attempted to duplicate the 
TABLE I

Pressures, Flows, Vascular Resistances, and Glomerular Permeability in Control Animals

\begin{tabular}{|c|c|c|c|c|c|c|c|}
\hline Rat & MAP & $P G$ & $P_{\boldsymbol{t}}$ & $\Delta P$ & sngfr & snff & $\mathrm{rpf}$ \\
\hline & $m m \mathrm{Hg}$ & $m m \mathrm{Hg}$ & $m m \mathrm{Hg}$ & $m m \mathrm{Hg}$ & $\begin{array}{c}n l / \min / g \\
k i d n e y\end{array}$ & & $\begin{array}{c}n l / m i n / g \\
\text { kidney }\end{array}$ \\
\hline \multirow[t]{2}{*}{ Control (11 rats) } & 122 & 59.5 & 20.3 & 38.1 & 47.7 & 0.25 & 200 \\
\hline & $\begin{array}{c} \pm 3 \\
(n=11)\end{array}$ & $\begin{array}{c} \pm 1.5 \\
(n=25)\end{array}$ & $\begin{array}{c} \pm 0.7 \\
(n=70)\end{array}$ & $\begin{array}{c} \pm 1.2 \\
(n=25)\end{array}$ & $\begin{array}{c} \pm 1.4 \\
(n=50)\end{array}$ & $\begin{array}{c} \pm 0.02 \\
(n=11)\end{array}$ & $\begin{array}{c} \pm 9 \\
(n=50)\end{array}$ \\
\hline \multicolumn{8}{|c|}{ Asn-1, Val-5 AII ( $\leqslant 5 \mathrm{ng}$ ) } \\
\hline \multirow[t]{2}{*}{4} & 129 & 61.9 & 17.2 & 42.8 & 33.2 & 0.30 & 111 \\
\hline & & \pm 1.0 & \pm 0.5 & \pm 1.0 & \pm 0.9 & & \pm 3 \\
\hline \multirow[t]{2}{*}{5} & 139 & 64.0 & 18.5 & 45.1 & 42.9 & 0.24 & 179 \\
\hline & & & \pm 0.5 & & \pm 1.9 & & \pm 8 \\
\hline \multirow[t]{2}{*}{6} & 144 & 63.8 & 20.8 & 44.5 & 35.3 & 0.35 & 101 \\
\hline & & \pm 3.4 & \pm 1.3 & \pm 0.8 & \pm 3.9 & & \pm 11 \\
\hline \multirow[t]{2}{*}{7} & 148 & 64.9 & 16.9 & 48.4 & 45.9 & 0.37 & 124 \\
\hline & & \pm 1.5 & \pm 0.9 & \pm 2.3 & \pm 4.3 & & \pm 11 \\
\hline \multirow[t]{2}{*}{8} & 105 & 64.9 & 15.1 & 50.4 & 26.6 & 0.35 & 76 \\
\hline & & \pm 2.1 & \pm 1.6 & \pm 3.7 & \pm 3.3 & & \pm 9 \\
\hline \multirow[t]{2}{*}{9} & 133 & 65.6 & 22.9 & 40.9 & 53.8 & 0.44 & 122 \\
\hline & & & \pm 0.2 & & \pm 4.8 & & \pm 11 \\
\hline \multirow[t]{2}{*}{ Overall mean } & 133 & 64.0 & 18.4 & 45.9 & 39.8 & 0.34 & 119 \\
\hline & $\begin{array}{c} \pm 6 \\
(n=6)\end{array}$ & $\begin{array}{c} \pm 0.8 \\
(n=52)\end{array}$ & $\begin{array}{c} \pm 0.6 \\
(n=38)\end{array}$ & $\begin{array}{c} \pm 1.3 \\
(n=12)\end{array}$ & $\begin{array}{c} \pm 2.2 \\
(n=29)\end{array}$ & $\begin{array}{c} \pm 0.03 \\
(n=6)\end{array}$ & $\begin{array}{c} \pm 7 \\
(n=29)\end{array}$ \\
\hline$P$ value $\ddagger$ & $>0.05$ & $<0.02$ & $<0.05$ & $<0.001$ & $<0.005$ & $<0.02$ & $<0.001$ \\
\hline
\end{tabular}

$*$ SEM.

$\ddagger$ Compared to control group.

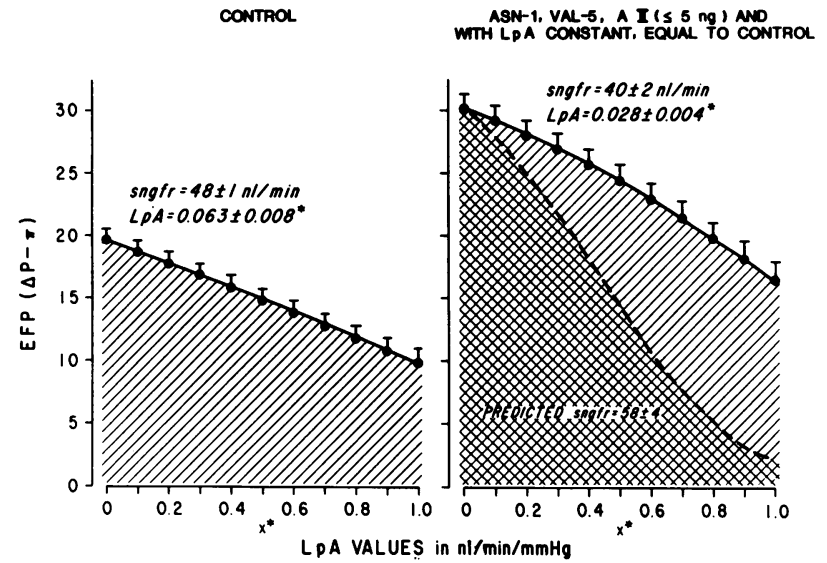

FIGURE 3 The profile of effective filtration pressure (EFP) along the glomerular capillary length $\left(x^{*}\right)$ in the control plasma-expanded group (left) and after the infusion of Asn-1, Val-5 AII ( $\leqslant \mathrm{ng} / 100 \mathrm{~g}$ body $\mathrm{wt} / \mathrm{min}$ ) (solid lines \pm SEM) (right). The measured sngfr in both conditions and the $L_{p} A$ are demonstrated. The dashed line (right) and doubly crossed hatched area designates the profile and area of the EFP function if $\mathrm{L}_{\mathrm{p}} \mathrm{A}$ had remained constant, equal to control values. The profile approached equilibrium and the total EFP profile was lower, but predicted sngfr would have been higher than control values $(58 \pm 4$ $\mathrm{nl} / \mathrm{min})$. protocol of the Asn-1, Val-5 AII group, in that subpressor quantities of Asp-1, Ile-5 AII were attempted. Because of the greater potency of this form of AII, sudden rises in MAP were the rule, even if the infusion rates were gradually increased. As a result, MAP was significantly higher than control at $146 \pm 4 \mathrm{~mm} \mathrm{Hg}(P<$ 0.001 ), although the maximum rate of infusion was 2.5 $\mathrm{ng} / 100 \mathrm{~g}$ body $\mathrm{wt} / \mathrm{min}$ in one rat and lower in the others.

The sngfr in this low-dose Asp-1, Ile-5 AII group was not different from the control value at $50.4 \pm 2.5(P>$ 0.3) (Table II). The $P_{t}$ was $17.4 \pm 0.6 \mathrm{~mm} \mathrm{Hg}$, significantly lower than control values $(P<0.01)$ as was the $\mathrm{HP}_{\mathrm{E}}(18.9 \pm 1.1, P<0.05)$. None of the factors that determine sngfr was altered from the control group values, although there was a trend towards a higher $\Delta P$ at $43.2 \pm 2.6 \mathrm{~mm} \mathrm{Hg}(P>0.05)$ (Fig. 1). The rpf was $233 \pm 25(P>0.2)$ and $\mathrm{rbf} 427 \pm 48 \mathrm{nl} / \mathrm{min} / \mathrm{g}$ kidney $(P>0.10)$ during the low-dose native AII infusion (Fig. 1). As reflected by the larger standard error for rpf and rbf in this group, there was a greater variability among animals in the response to low-dose AII. When data were analyzed from animal mean values there were also no significant differences in sngfr or determinants of filtration. AR and ER were nearly identical to the 
and after the Infusion of Asn-1, Val-5 AII ( $<5 \mathrm{ng} / 100 \mathrm{~g}$ body wt/min)

\begin{tabular}{|c|c|c|c|c|c|c|c|c|}
\hline rbf & AR & ER & $\mathrm{HP}_{\boldsymbol{B}}$ & $\pi_{A}$ & $\pi_{B}$ & $\overline{\mathrm{EFP}}$ & $\mathrm{L}_{\mathrm{p}} \mathrm{A}$ & $\operatorname{EFP}_{B}$ \\
\hline $\begin{array}{c}n l / \min / g \\
\text { kidney }\end{array}$ & $\begin{array}{c}\times 100 d y n \\
s / c^{5}\end{array}$ & $\begin{array}{c}\times 10^{\circ} d y n \\
s / c^{6}\end{array}$ & $m m \mathrm{Hg}$ & $m m \mathrm{Hg}$ & $m m \mathrm{Hg}$ & $m m \mathrm{Hg}$ & $\begin{array}{r}n l / s / g \\
k i d n e y / \\
m m H g\end{array}$ & $m m \mathrm{Hg}$ \\
\hline 346 & 16.8 & 10.4 & 22.9 & 18.4 & 28.4 & 14.5 & 0.063 & 9.5 \\
\hline $\begin{array}{c} \pm 16 \\
(n=50)\end{array}$ & $\begin{array}{c} \pm 2.4 \\
(n=11)\end{array}$ & $\begin{array}{c} \pm 0.8 \\
(n=11)\end{array}$ & $\begin{array}{c} \pm 1.2 \\
(n=25)\end{array}$ & $\begin{array}{c} \pm 0.5 \\
(n=11)\end{array}$ & $\begin{array}{c} \pm 0.8 \\
(n=11)\end{array}$ & $\begin{array}{c} \pm 1.6 \\
(n=11)\end{array}$ & $\begin{array}{c} \pm 0.008^{*} \\
(n=11)\end{array}$ & $\begin{array}{c} \pm 1.7 \\
(n=11)\end{array}$ \\
\hline 188 & 28.7 & 22.3 & 18.4 & 14.8 & 25.3 & 23.3 & 0.024 & 17.5 \\
\hline \pm 6 & & & \pm 1.2 & & & \pm 0.9 & \pm 0.001 & \\
\hline 316 & 19.2 & 12.0 & 24.2 & 18.0 & 27.0 & 22.9 & 0.031 & 18.1 \\
\hline \pm 14 & & & \pm 0.7 & & & & \pm 0.001 & \\
\hline 168 & 38.3 & 28.7 & 15.5 & 13.5 & 25.3 & 25.9 & 0.023 & 19.2 \\
\hline \pm 19 & & & \pm 1.0 & & & \pm 0.4 & \pm 0.002 & \\
\hline 230 & 28.7 & 22.3 & 13.8 & 16.6 & 33.1 & 24.3 & 0.031 & 15.3 \\
\hline \pm 22 & & & \pm 1.9 & & & \pm 1.9 & \pm 0.003 & \\
\hline 146 & 21.5 & 34.3 & 14.0 & 18.0 & 35.0 & 24.7 & 0.018 & 15.4 \\
\hline \pm 18 & & & \pm 0.1 & & & \pm 3.2 & \pm 0.002 & \\
\hline 231 & 23.1 & 20.0 & 21.9 & 13.1 & 30.6 & 20.1 & 0.044 & 10.3 \\
\hline \pm 20 & & & \pm 1.9 & & & & \pm 0.003 & \\
\hline 214 & 26.3 & 23.1 & 17.8 & 15.7 & 29.4 & 23.5 & 0.028 & 16.0 \\
\hline \pm 12 & \pm 3.2 & \pm 3.2 & \pm 1.0 & \pm 0.9 & \pm 1.7 & \pm 0.8 & \pm 0.004 & \pm 1.3 \\
\hline$(n=29)$ & $(n=6)$ & $(n=6)$ & $(n=20)$ & $(n=6)$ & $(n=6)$ & $(n=6)$ & $(n=6)$ & $(n=6)$ \\
\hline$<0.001$ & $<0.02$ & $<0.001$ & $<0.005$ & $<0.02$ & $>0.50$ & $<0.005$ & $<0.02$ & $<0.001$ \\
\hline
\end{tabular}

control values $(P>0.8)$. The snff was also nearly identical to the control value at $0.23 \pm 0.04(P>0.60)$. All data are shown in Table II. Both $\pi_{A}$ and $\pi_{k}$ were unchanged, but hematocrit was significantly higher at $45 \pm 2(P<0.05)$.

GFR in this group was $1.47 \pm 0.1(n=6)$, very similar to the control group value $(1.50 \pm 0.20 \mathrm{ml} / \mathrm{min} / \mathrm{g}$ kidney, $P>0.90)$. Renal plasma flow was $4.1 \pm 0.5 \mathrm{nl} / \mathrm{min} / \mathrm{g}$ kidney and renal blood flow $7.6 \pm 0.9 \mathrm{nl} / \mathrm{min} / \mathrm{g}$ kidney $(n=3)$.

Although sngfr was unchanged from the control group, the EFP $P_{\mathrm{x}}$ tended to be higher, $14.5 \pm 2.1 \mathrm{~mm}$ $\mathrm{Hg}$ compared to $9.5 \pm 1.7 \mathrm{~mm} \mathrm{Hg}$, but did not achieve statistical significance $(0.1>P>0.05)$. The $\overline{\mathrm{EFP}}$ was also numerically higher at $19.5 \pm 1.9 \mathrm{~mm} \mathrm{Hg}$ but also not significantly $(0.1>P>0.05)$. Similarly, the $\mathrm{L}_{\mathrm{p}} \mathrm{A}$ was $0.044 \pm 0.007 \mathrm{nl} / \mathrm{s} / \mathrm{g}$ kidney $\mathrm{mm} \mathrm{Hg}$ compared to $0.063 \pm$ 0.008 in control $(0.20>P>0.10)$. In summary, minimum pressor quantities of Asp-1, Ile-5 AII produce no alterations in either sngfr or factors that determine sngfr. There was a tendency towards a lower $L_{p} A$ and higher $\overline{\mathrm{EFP}}$. In spite of significant peripheral vasoconstrictor effect as evidenced by increased MAP, there was no significant effect on either renal vascular resistances or $L_{p} A$.
Effects of high-dose Asp-1, Ile-5 AII. The lack of significant effect of this form of AII in lower doses may have resulted solely from the reduced quantity of AII delivered to the kidney. We have therefore infused at least $5 \mathrm{ng} / 100 \mathrm{~g}$ body $\mathrm{wt} / \mathrm{min}$ of the native AII to duplicate the quantities of Asn-1, Val-5 AII infused (subpressor dose). It was recognized that this infusion rate would consistently produce systemic hypertension. The MAP was $143 \pm 4 \mathrm{~mm} \mathrm{Hg}$, significantly higher than control $(122 \pm 3 \mathrm{~mm} \mathrm{Hg}, P<0.001)$, but in spite of the greater infusion rate, not different from the lower dose group. The sngfr was reduced to $34.0 \pm 2.3 \mathrm{nl} / \mathrm{min} / \mathrm{g}$ kidney with the higher dose of native AII, a value similar to that in the Asn-1, Val-5 AII group after similar quantities of AII. All factors measured are shown in Table III, and the values are strikingly similar to the values obtained when Asn-1, Val-5 AII was administered in similar quantities. Both the AR and ER increased to $38 \pm 6 \times 10^{\circ}(P<0.005)$ and $27 \pm 4 \times 10^{\circ}$ dyn $\mathrm{s} \mathrm{cm}^{-\mathrm{s}}(P<0.001)$ respectively, and, as a result, rpf fell to $99.3 \pm 6.5 \mathrm{nl} / \mathrm{min} / \mathrm{g}$ kidney $(P<0.001)$ and $\mathrm{rbf}$ to $182 \pm 14 \mathrm{nl} / \mathrm{min} / \mathrm{g}$ kidney $(P<0.001)$ (Fig. 1$)$.

When data were also analyzed from mean values, the sngfr fell from $47.3 \pm 2.4$ in control to $35.6 \pm 4.3 \mathrm{nl} / \mathrm{min} / \mathrm{g}$ kidney $(P<0.05)$ after Asp-1, Ile-5 AII, the rpf from 
TABLE II

Pressures, Flows, Vascular Resistances, and Glomerular Permeability in Control Animals

\begin{tabular}{|c|c|c|c|c|c|c|c|}
\hline Rat & MAP & $P_{\theta}$ & $P_{\boldsymbol{t}}$ & $\Delta P$ & sngfr & snff & $\mathrm{rpf}$ \\
\hline & $m m \mathrm{Hg}$ & $m m H_{g}$ & $m m \mathrm{Hg}$ & $m m H_{g}$ & $\begin{array}{c}n l / \min / g \\
\text { kidney }\end{array}$ & & $\begin{array}{c}n l / m i n / g \\
k i d n e y\end{array}$ \\
\hline \multirow{2}{*}{ Control (11 rats) } & 122 & 59.5 & 20.3 & 38.1 & 47.7 & 0.25 & 200 \\
\hline & $\begin{array}{c} \pm 3 \\
(n=11)\end{array}$ & $\begin{array}{c} \pm 1.5 \\
(n=25)\end{array}$ & $\begin{array}{c} \pm 0.7 \\
(n=70)\end{array}$ & $\begin{array}{c} \pm 1.2 \\
(n=25)\end{array}$ & $\begin{array}{c} \pm 1.4 \\
(n=50)\end{array}$ & $\begin{array}{c} \pm 0.02 \\
(n=11)\end{array}$ & $\begin{array}{c} \pm 9 \\
(n=50)\end{array}$ \\
\hline \multicolumn{8}{|c|}{ Asp-1, Ile-5 AII ( $<3 \mathrm{ng}$ ) } \\
\hline \multirow[t]{2}{*}{10} & 159 & 60.6 & 22.5 & 36.7 & 55.9 & & \\
\hline & & \pm 3.8 & \pm 0.3 & \pm 3.5 & \pm 3.5 & & \\
\hline \multirow[t]{2}{*}{11} & 148 & 65.2 & 14.8 & 47.9 & 70.7 & 0.16 & 442 \\
\hline & & & \pm 0.4 & & \pm 2.5 & & \pm 16 \\
\hline \multirow[t]{2}{*}{12} & 134 & 64.0 & 12.4 & 46.8 & 39.8 & 0.31 & 128 \\
\hline & & & \pm 0.3 & & \pm 3.7 & & \pm 12 \\
\hline \multirow[t]{2}{*}{13} & 135 & 51.6 & 15.7 & 35.6 & 42.8 & 0.28 & 153 \\
\hline & & & \pm 0.5 & & \pm 4.6 & & \pm 16 \\
\hline 14 & 149 & & & & $\begin{array}{r}44.2 \\
\pm 5.6\end{array}$ & 0.29 & $\begin{array}{r}152 \\
\pm 19\end{array}$ \\
\hline \multirow[t]{2}{*}{15} & 148 & 66.4 & 22.0 & 47.4 & 48.3 & 0.17 & 284 \\
\hline & & \pm 5.2 & \pm 1.0 & \pm 4.6 & \pm 5.3 & & \pm 31 \\
\hline \multirow[t]{2}{*}{ Overall mean } & 146 & 62.7 & 17.4 & 43.2 & 50.4 & 0.23 & 233 \\
\hline & $\begin{array}{c} \pm 4 \\
(n=6)\end{array}$ & $\begin{array}{c} \pm 2.6 \\
(n=8)\end{array}$ & $\begin{array}{c} \pm 0.6 \\
(n=38)\end{array}$ & $\begin{array}{c} \pm 2.6 \\
(n=8)\end{array}$ & $\begin{array}{c} \pm 2.5 \\
(n=30)\end{array}$ & $\begin{array}{c} \pm 0.04 \\
(n=4)\end{array}$ & $\begin{array}{c} \pm 25 \\
(n=25)\end{array}$ \\
\hline$P$ value $\ddagger$ & $<0.001$ & $>0.20$ & $<0.01$ & $>0.05$ & $>0.30$ & $>0.60$ & $>0.20$ \\
\hline
\end{tabular}

* \pm SEM.

$\ddagger$ Compared to control group.

$198 \pm 18$ to $99 \pm 12 \mathrm{nl} / \mathrm{min} / \mathrm{g}$ kidney $(P<0.005)$ after AII, and rbf from $344 \pm 32$ to $181 \pm 26 \mathrm{nl} / \mathrm{min} / \mathrm{g}$ kidney $(P<0.005)$. The changes are similar but slightly greater than values observed after Asn-1, Val-5 AII. In addition, the increase in renal vascular resistance and consequent reduction in nephron blood flow with Asp-1, Ile-5 AII did not correlate in dose response to the peripheral vasoconstrictor activity, since MAP was elevated to a similar degree in the low-dose group but without an observable increase in either $A R$ or $E R$ and consequently no reduction in either rpf or rbf.

The $P_{a}$ again increased, as with similar doses of Asn-1, Val-5 AII, to $67.0 \pm 2.0 \mathrm{~mm} \mathrm{Hg}(P<0.005)$ and $P_{t}$ also fell to $15.5 \pm 0.4 \mathrm{~mm} \mathrm{Hg}(P<0.001)$. Therefore $\Delta \mathrm{P}$ increased to $51.7 \pm 2.1 \mathrm{~mm} \mathrm{Hg}$ as compared to $38.1 \pm$ 1.2 in the control group $(P<0.001)$. When changes were analyzed from mean animal values, $\Delta \mathrm{P}$ increased from $37.9 \pm 1.3$ in control to $51.3 \pm 1.5 \mathrm{~mm} \mathrm{Hg}(P<$ $0.001)$. The $\pi_{\Delta}$ was $19.2 \pm 1.3 \mathrm{~mm} \mathrm{Hg}(P>0.50)$ and $\pi_{B}$ was significantly higher at $38.3 \pm 2.3 \mathrm{~mm} \mathrm{Hg}(P<$ $0.005)$. The hematocrit was $44 \pm 1 \%$, not different from the control values $(P>0.10) . \mathrm{HP}_{z}$ was not different from control at $21.7 \pm 1.2 \mathrm{~mm} \mathrm{Hg}(P>0.40)$. The snff was very similar to the value in the Asn-1, Val-5 AII group at $0.36 \pm 0.03$ and was again significantly higher than the snff in the control group $(P<0.01)$.

GFR during Asp-1, Ile-5 AII was $1.12 \pm 0.1 \mathrm{ml} / \mathrm{min} / \mathrm{g}$ kidney $(N=6)$, very similar to the value during similar quantities of the synthetic AII $(1.10 \pm 0.08 \mathrm{ml} / \mathrm{min} / \mathrm{g}$ kidney). Renal plasma flow was $2.8 \pm 0.6 \mathrm{ml} / \mathrm{min} / \mathrm{g}$ kidney and renal blood flow $4.8 \pm 1.0 \mathrm{ml} / \mathrm{min} / \mathrm{g}$ kidney $(N=3)$.

In spite of the decrease in rpf with high dose Asp-1, Ile-5 AII, the EFPs remained high at $13.0 \pm 2.5 \mathrm{~mm} \mathrm{Hg}$ $(P>0.20)$. The rate of $\mathrm{rpf}$ in this group was quite similar to hydropenic values, where filtration pressure equilibrium occurs, due to the high $\mathrm{L}_{\mathrm{p}} \mathrm{A}$. The $\overline{\mathrm{EFP}}$ was significantly increased to $23.2 \pm 2.1 \mathrm{~mm} \mathrm{Hg}(P<0.005)$. Again the increase in $\Delta P$ neutralized the effect of reduced rpf, and $\overline{E F P}$ should not have changed if these were the only effects of high dose Asp-1, Ile-5 AII. The $\mathrm{L}_{\mathrm{p}} \mathrm{A}$ was also reduced with this infusion rate of native $\mathrm{AII}$ at $0.026 \pm 0.004 \mathrm{nl} / \mathrm{s} / \mathrm{g}$ kidney $\mathrm{mm} \mathrm{Hg}(P<0.001)$. This value for $L_{p} A$ was quite similar to the value produced by similar quantities of Asn-1, Val-5 AII (0.028士 $0.004 \mathrm{nl} / \mathrm{s} / \mathrm{g}$ kidney $/ \mathrm{mm} \mathrm{Hg}$ ). The increase in $\overline{\mathrm{EFP}}$ was again primarily the result of the large reduction in $L_{p} A$ after AII. 
and after the Infusion of Low-Dose Asp-1, Ile-5 AII (<3 ng/100 g body wt./min)

\begin{tabular}{|c|c|c|c|c|c|c|c|c|}
\hline $\mathrm{rbf}$ & AR & ER & $\mathrm{HP}_{\mathrm{B}}$ & $x_{A}$ & $\pi_{B}$ & $\overline{\mathrm{EFP}}$ & $\mathrm{L}_{\mathrm{p} A}$ & EFPs \\
\hline $\begin{array}{c}n l / \min / g \\
\text { kidney }\end{array}$ & $\begin{array}{c}\times 10^{\circ} d y n \\
\mathrm{~s} / \mathrm{cm}^{\mathrm{s}}\end{array}$ & $\begin{array}{l}\times 10^{0} d y n \\
s / c^{5}\end{array}$ & $m m H_{g}$ & $m m \mathrm{Hg}$ & $m m \mathrm{Hg}_{\mathrm{g}}$ & $m m H_{g}$ & $\begin{array}{r}n l / s / g \\
k i d n e y / \\
m m ~ H g\end{array}$ & $m m \mathrm{Hg}$ \\
\hline 346 & 16.8 & 10.4 & 22.9 & 18.4 & 28.4 & 14.5 & 0.063 & 9.5 \\
\hline \multirow[t]{2}{*}{$\begin{array}{c} \pm 16 \\
(n=50)\end{array}$} & $\begin{array}{c} \pm 2.4 \\
(n=11)\end{array}$ & $\begin{array}{c} \pm 0.8 \\
(n=11)\end{array}$ & $\begin{array}{c} \pm 1.2 \\
(n=25)\end{array}$ & $\begin{array}{c} \pm 0.5 \\
(n=11)\end{array}$ & $\begin{array}{c} \pm 0.8 \\
(n=11)\end{array}$ & $\begin{array}{c} \pm 1.6 \\
(n=11)\end{array}$ & $\begin{array}{c} \pm 0.008^{*} \\
(n=11)\end{array}$ & $\begin{array}{c} \pm 1.7 \\
(n=11)\end{array}$ \\
\hline & & & $\begin{array}{r}21.7 \\
\pm 1.4\end{array}$ & 17.1 & & & & \\
\hline $\begin{array}{r}819 \\
\pm 29\end{array}$ & 8.0 & 5.2 & $\begin{array}{r}16.3 \\
+1.7\end{array}$ & 24.8 & 32.5 & 19.4 & $\begin{array}{r}0.061 \\
+0.002\end{array}$ & 15.4 \\
\hline 229 & 24.7 & 21.5 & 13.3 & 16.6 & 28.8 & 24.7 & $\begin{array}{r} \pm 0.002 \\
0.026\end{array}$ & 18.0 \\
\hline \pm 21 & & & \pm 1.6 & & & & \pm 0.002 & \\
\hline 261 & 25.5 & 11.2 & 21.2 & 15.2 & 24.8 & 15.9 & 0.045 & 10.8 \\
\hline $\begin{array}{r} \pm 68 \\
293\end{array}$ & & & \pm 1.3 & 20.5 & 35.0 & & \pm 0.003 & \\
\hline \pm 37 & & & & & & & & \\
\hline 527 & 12.0 & 7.2 & 22.0 & 25.3 & 33.7 & 18.0 & 0.044 & 13.7 \\
\hline \pm 58 & & & \pm 2.6 & & & \pm 4.0 & \pm 0.011 & \\
\hline 427 & 17.6 & 11.6 & 18.9 & 19.9 & 31.0 & 19.5 & 0.044 & 14.5 \\
\hline $\begin{array}{c} \pm 48 \\
(n=25) \\
-0.10\end{array}$ & $\begin{array}{c} \pm 4.8 \\
(n=4) \\
>0.80\end{array}$ & $\begin{array}{c} \pm 4.0 \\
(n=4) \\
>0.80\end{array}$ & $\begin{array}{c} \pm 1.1 \\
(n=15) \\
>0.05\end{array}$ & $\begin{array}{c} \pm 1.8 \\
(n=6) \\
>0.20\end{array}$ & $\begin{array}{c} \pm 1.9 \\
(n=5) \\
>010\end{array}$ & $\begin{array}{c} \pm 1.9 \\
(n=6) \\
>0.05\end{array}$ & $\begin{array}{c} \pm 0.007 \\
(n=4) \\
>010\end{array}$ & $\begin{array}{c} \pm 2.1 \\
(n=4) \\
>0.05\end{array}$ \\
\hline
\end{tabular}

A peripheral vasoconstrictor effect was seen only with Asp-1, Ile-5 AII. Although lower doses of this agent produced an increased MAP, no effect on either $L_{p} A$ or rpf was observed.

In the study of Hornych et al. (9), an increase in urinary protein excretion was noted with the infusion of Asn-1, Val-5 AII. They also noted "fusion" of foot processess of the epithelial cells of the glomerular capillary, as evaluated by scanning electron microscopy. Urinary protein excretion in this study averaged $6.4 \pm 2.5$ $\mu \mathrm{g} / \mathrm{min}$ in the control plasma-expanded rats and was $8.1 \pm 0.8(P>0.80)$ in the Asn-1, Val-5 AII group, and $9.0 \pm 3.0 \mu \mathrm{g} / \mathrm{min}(P>0.50)$ in the high-dose group. Protein electrophoresis of samples from each group revealed no significant changes in the ratio of albumin to globulin.

Plasma sodium and potassium concentrations were not different among experimental groups. Urine sodium excretion $\left(\mathrm{U}_{\mathrm{Na}} \mathrm{V}\right.$ ) was $2.5 \pm 0.3 \mu \mathrm{eq} / \mathrm{min}$ from the left control kidney and fractional excretion, $\left(\mathrm{FE}_{\mathrm{Na}}=\mathrm{C}_{\mathrm{Na}} / \mathrm{GFR}\right.$ $\times 100 \%$ ) $1.7 \pm 0.2 \%$. The left kidney values for the Asn-1, Val-5 AII group was $2.0 \pm 1.2 \mu \mathrm{eq} / \mathrm{min}$ for $U_{\mathrm{Na}} \mathrm{V}$ $(P>0.5)$ and $1.8 \pm 0.7 \%$ for $\mathrm{FE}_{\mathrm{Na}}(P>0.8)$. $\mathrm{U}_{\mathrm{Na}} \mathrm{V}$ was $3.1 \pm 0.6 \mu \mathrm{eq} / \mathrm{min}(P>0.4)$ and $\mathrm{FE}_{\mathrm{Na}} 2.1 \pm 0.6 \%$
$(P>0.5)$ in the low-dose Asp-1, Ile-5 AII group. $\mathrm{U}_{\mathrm{Na}} \mathrm{V}$ was $5.5 \pm 1.7 \mu \mathrm{eq} / \mathrm{min}(P>0.1)$ and $\mathrm{FE}_{\mathrm{Na}} 3.1 \pm$ $1.4 \%(P>0.3)$ in the higher-dose Asp-1, Ile-5 AII group. Urinary potassium excretion $\left(U_{\mathbf{k} V}\right)$ was also unaltered by AII infusion.

In Fig. 4, the association of changes in afferent and efferent resistances with the changes in $L_{p} A$ is demonstrated. The correlation was rather striking where high resistances at both afferent and efferent arterioles were associated with lower values for $L_{p} A$ in the $5 \mathrm{ng} / 100 \mathrm{~g}$ body wt/ $\min$ AII groups.

Paired studies on the effect of Asp-1, Ile-5 AII. Unpaired group studies were performed because of the concern that the added effects of time and lesser degrees of volume expansion, inherent with paired studies, would result in the intrarenal release of endogenous AII. This could theoretically have increased the variability of response to AII. However, to demonstrate that the AII effects can be shown with the animal as its own control, a series of paired studies were performed, utilizing pressor doses of Asp-1, Ile-5 AII.

As demonstrated in Table IV, changes in rpf in paired studies were nearly identical to the changes in group studies (higher-dose Asp-1, Val-5 AII groups). 
TABLE III

Pressures, Flows, Vascular Resistances, and Glomerular Permeability in Control Animals

\begin{tabular}{|c|c|c|c|c|c|c|c|}
\hline Rat & MAP & $P a$ & $P_{\boldsymbol{t}}$ & $\Delta P$ & sngfr & snff & $\mathrm{rpf}$ \\
\hline & $m m \mathrm{Hg}$ & $m m \mathrm{Hg}_{\mathrm{g}}$ & $m m \mathrm{Hg}$ & $m m \mathrm{Hg}$ & $\underset{\text { kidney }}{n l / \min / \mathrm{g}}$ & & $\begin{array}{c}n l / \min / \mathrm{g} \\
k i d n e y\end{array}$ \\
\hline \multirow[t]{2}{*}{ Control (11 rats) } & 122 & 59.5 & 20.3 & 38.1 & 47.7 & 0.25 & 200 \\
\hline & $\begin{array}{c} \pm 3 \\
(n=11)\end{array}$ & $\begin{array}{c} \pm 1.5 \\
(n=25)\end{array}$ & $\begin{array}{c} \pm 0.7 \\
(n=70)\end{array}$ & $\begin{array}{c} \pm 1.2 \\
(n=25)\end{array}$ & $\begin{array}{c} \pm 1.4 \\
(n=50)\end{array}$ & $\begin{array}{c} \pm 0.02 \\
(n=11)\end{array}$ & $\begin{array}{c} \pm 9 \\
(n=50)\end{array}$ \\
\hline \multicolumn{8}{|c|}{ Asp-1, Ile-5 AII ( $>5 \mathrm{ng}$ ) } \\
\hline \multirow[t]{2}{*}{17} & 149 & 65.5 & 13.8 & 55.9 & 45.3 & 0.40 & 109 \\
\hline & & & \pm 0.8 & & \pm 3.4 & & \pm 8 \\
\hline \multirow[t]{2}{*}{18} & 130 & 66.4 & 16.1 & 48.3 & 42.5 & 0.29 & 147 \\
\hline & & & \pm 0.8 & & \pm 4.9 & & \pm 17 \\
\hline \multirow[t]{2}{*}{19} & 146 & 62.3 & 16.6 & 46.3 & 28.7 & 0.39 & 74 \\
\hline & & & \pm 0.9 & & \pm 1.9 & & \pm 5 \\
\hline \multirow[t]{2}{*}{20} & 140 & 70.6 & 16.1 & 54.6 & 40.6 & 0.37 & 110 \\
\hline & & \pm 0.6 & \pm 0.5 & \pm 0.9 & \pm 3.8 & & \pm 10 \\
\hline \multirow[t]{2}{*}{23} & 156 & 65.8 & 14.3 & 51.2 & 38.8 & 0.47 & 82 \\
\hline & & \pm 9.3 & \pm 1.0 & \pm 9.1 & \pm 3.4 & & \pm 7 \\
\hline \multirow[t]{2}{*}{24} & 136 & 69.3 & 16.6 & 51.3 & 17.5 & 0.24 & 73 \\
\hline & & & \pm 0.9 & & \pm 1.5 & & \pm 6 \\
\hline \multirow[t]{2}{*}{ Overall mean } & 143 & 67.0 & 15.5 & 51.7 & 35.0 & 0.36 & 99 \\
\hline & $\begin{array}{c} \pm 4 \\
(n=6)\end{array}$ & $\begin{array}{c} \pm 2.0 \\
(n=8)\end{array}$ & $\begin{array}{c} \pm 0.4 \\
(n=35)\end{array}$ & $\begin{array}{c} \pm 2.1 \\
(n=8)\end{array}$ & $\begin{array}{c} \pm 2.3 \\
(n=27)\end{array}$ & $\begin{array}{c} \pm 0.03 \\
(n=6)\end{array}$ & $\begin{array}{c} \pm 6 \\
(n=27)\end{array}$ \\
\hline$P$ value $f$ & $<0.001$ & $<0.005$ & $<0.001$ & $<0.001$ & $<0.001$ & $<0.01$ & $<0.001$ \\
\hline
\end{tabular}

$*$ SEM.

$\ddagger$ Compared to control group.

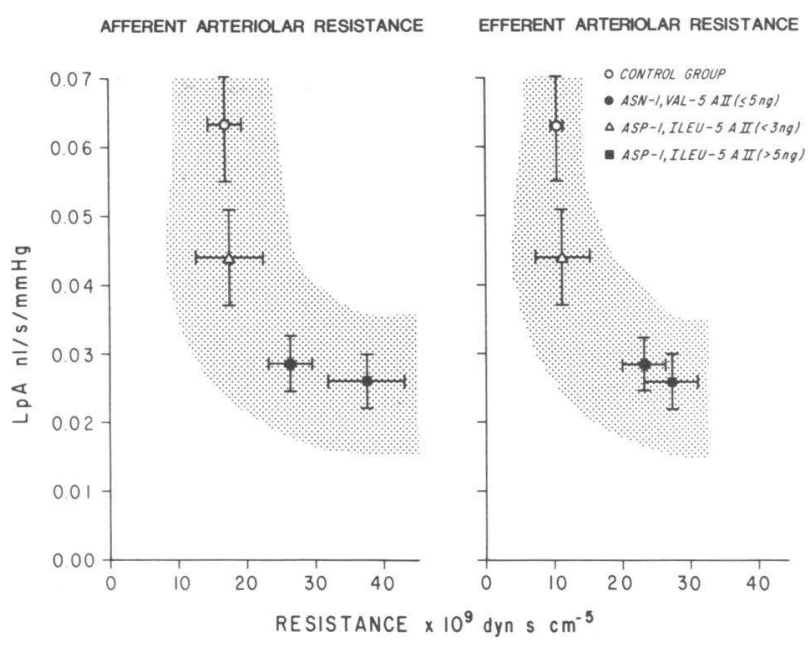

FIGURE $4 \mathrm{~A}$ comparison of the resulting afferent and efferent arteriolar resistances with the corresponding values for the glomerular permeability coefficient $\left(L_{p} A\right)$ for the three AII infused groups and the control group. Each value is delineated as the mean \pm SEM of each value. The shaded portions on each graph define the range of values delineated by one standard deviation for both $\mathrm{L}_{\mathrm{p}} \mathrm{A}$ and resistances. Higher values for vascular resistances correlate with the lower values for $L_{p} A$ after higher doses of AII.
The reduction in $L_{p} A$ and increase in $\Delta P$ were greater in the paired studies. The greater rise in $\Delta P(57.7 \pm 2.7$ from $40.8 \pm 1.7 \mathrm{~mm} \mathrm{Hg}$ ) was the result of the larger increase in $P_{G}$ (from $60.4 \pm 2.0$ to $72.6 \pm 3.4 \mathrm{~mm} \mathrm{Hg}$ ). The quantitative reduction in sngfr from $56.3 \pm 2.8$ to $33.4 \pm 2.5 \mathrm{nl} / \mathrm{min} / \mathrm{g}$ kidney $(P<0.001)$ was also more dramatic in paired studies even though a lesser dose of Asp-1, Ile-5 AII ( $\approx 4 \mathrm{ng} / 100 \mathrm{~g}$ body wt/min) was required to elevate blood pressure by $25 \mathrm{~mm} \mathrm{Hg}$.

In the control plasma expansion state $\operatorname{EFP}_{\boldsymbol{s}}$ was $9.4 \pm 3.1 \mathrm{~mm} \mathrm{Hg}$, nearly identical to the group control value, $9.5 \pm 1.7 \mathrm{~mm} \mathrm{Hg}$. The EFP $_{\boldsymbol{s}}$ after Asp-1, Ile-5 AII was much higher than both control values and values for the other AII groups at $26.0 \pm 3.5(P<0.001)$. The $\mathrm{L}_{\mathrm{p}} \mathrm{A}$ in the control group averaged $0.061 \pm 0.001 \mathrm{nl} / \mathrm{s} / \mathrm{g}$ kidney $\mathrm{mm} \mathrm{Hg}$ and fell in each paired study to a mean value of $0.017 \pm 0.002(P<0.001)$. The $\overline{\mathrm{EFP}}$ rose from $15.9 \pm 2.0 \mathrm{~mm} \mathrm{Hg}$ in control to $33.5 \pm 3.4 \mathrm{~mm} \mathrm{Hg}(P<$ 0.001 ).

The snff was $0.27 \pm 0.04$ in control and $0.32 \pm 0.01$ during AII. Systemic protein concentration was $5.8 \pm 0.3$ $\mathrm{g} / 100 \mathrm{ml}$ during the control condition and $5.2 \pm 0.2 \mathrm{~g} / 100$ $\mathrm{ml}$ during AII infusion. The hematocrit was $44 \pm 1 \%$ in 
and after the Infusion of Asp-1, Ile-5 AII (>5 ng/100 $\mathrm{g}$ body wt/min)

\begin{tabular}{|c|c|c|c|c|c|c|c|c|}
\hline rbf & AR & ER & $\mathrm{HP}_{\boldsymbol{B}}$ & $\pi_{A}$ & $\pi_{B}$ & $\overline{\text { EFP }}$ & $\mathbf{L}_{\mathrm{p}} \mathbf{A}$ & $\operatorname{EFP}_{B}$ \\
\hline $\begin{array}{c}n l / \min / g \\
k i d n e y\end{array}$ & $\begin{array}{l}\times 100 d y n \\
s / c^{5}\end{array}$ & $\begin{array}{c}\times 10^{\circ} d y n \\
s / \mathrm{cm}^{5}\end{array}$ & $m m H_{g}$ & $m m \mathrm{Hg}_{\mathrm{g}}$ & $m m H_{g}$ & $m m H_{g}$ & $\begin{array}{c}n l / s / g \\
k i d n e y / \\
m m H g\end{array}$ & $m m \mathrm{Hg}$ \\
\hline 346 & 16.8 & 10.4 & 22.9 & 18.4 & 28.4 & 14.5 & 0.063 & 9.5 \\
\hline $\begin{array}{c} \pm 16 \\
(n=50)\end{array}$ & $\begin{array}{c} \pm 2.4 \\
(n=11)\end{array}$ & $\begin{array}{c} \pm 0.8 \\
(n=11)\end{array}$ & $\begin{array}{c} \pm 1.2 \\
(n=25)\end{array}$ & $\begin{array}{c} \pm 0.5 \\
(n=11)\end{array}$ & $\begin{array}{c} \pm 0.8 \\
(n=11)\end{array}$ & $\begin{array}{c} \pm 1.6 \\
(n=11)\end{array}$ & $\begin{array}{c} \pm 0.008^{*} \\
(n=11)\end{array}$ & $\begin{array}{c} \pm 1.7 \\
(n=11)\end{array}$ \\
\hline 190 & 35.1 & 25.5 & 19.5 & 15.2 & 33.1 & 33.2 & 0.022 & 22.8 \\
\hline \pm 15 & & & \pm 0.6 & & & & $\pm 0.001^{*}$ & \\
\hline 294 & 17.6 & 12.0 & 28.5 & 21.6 & 36.3 & 19.7 & 0.036 & 12.0 \\
\hline \pm 34 & & & \pm 0.9 & & & & \pm 0.003 & \\
\hline 125 & 53.5 & 31.1 & 24.5 & 16.2 & 34.4 & 21.9 & 0.022 & 11.9 \\
\hline \pm 8 & & & \pm 2.0 & & & & \pm 0.001 & \\
\hline 200 & 27.9 & 25.5 & 19.0 & 21.6 & 44.7 & 22.0 & 0.031 & 9.9 \\
\hline \pm 19 & & & \pm 0.7 & & & \pm 0.8 & \pm 0.002 & \\
\hline 142 & 51.1 & 39.9 & 14.2 & 17.6 & 46.2 & 19.6 & 0.033 & 5.0 \\
\hline \pm 13 & & & \pm 1.4 & & & \pm 7.4 & \pm 0.02 & \\
\hline 135 & 39.1 & 29.5 & 25.6 & 23.1 & 35.0 & 22.5 & 0.013 & 16.3 \\
\hline \pm 12 & & & \pm 1.0 & & & & \pm 0.001 & \\
\hline 182 & 37.5 & 27.1 & 21.7 & 19.2 & 38.3 & 23.2 & 0.026 & 13.0 \\
\hline $\begin{array}{c} \pm 14 \\
(n=27)\end{array}$ & $\begin{array}{c} \pm 5.6 \\
(n=6)\end{array}$ & $\begin{array}{c} \pm 4.0 \\
(n=6)\end{array}$ & $\begin{array}{c} \pm 1.2 \\
(n=19)\end{array}$ & $\begin{array}{c} \pm 1.3 \\
(n=6)\end{array}$ & $\begin{array}{c} \pm 2.3 \\
(n=6)\end{array}$ & $\begin{array}{c} \pm 2.1 \\
(n=6)\end{array}$ & $\begin{array}{l} \pm 0.004 \\
(n=6)\end{array}$ & $\begin{array}{c} \pm 2.5 \\
(n=6)\end{array}$ \\
\hline$<0.001$ & $<0.005$ & $<0.001$ & $>0.40$ & $>0.50$ & $<0.005$ & $<0.005$ & $<0.001$ & $>0.20$ \\
\hline
\end{tabular}

the control state and $46 \pm 1 \%$ during AII infusion $(P>$ $0.8)$.

Therefore both unpaired and paired studies have revealed that AII, when infused in sufficient but modest quantities, produces a dramatic reduction in $L_{p} A$.

\section{DISCUSSION}

Utilizing both synthetic and endogenously produced forms of AII (13), we have demonstrated an effect of this hormone upon nephron filtration rate, nephron plasma flow, the hydrostatic pressure gradient, and the glomerular permeability coefficient in both paired and group studies. The specific role of AII in volume homeostasis has been related to the capacity to regulate aldosterone release $(7,26)$ and has been proposed to regulate the rate of glomerular filtration through its intrarenal release via tubulo-glomerular feedback (27-34). Specific quantitative observations on the effects of AII on the glomerular permeability coefficient have not been previously described, although previous studies have speculated that AII might reduce glomerular capillary radius $(9,10)$. This effect might be mediated by activation of contractile properties of the mesangial cell (35). Studies have also permitted some insights into the relative peripheral and glomerular effects of the two forms of AII.

The effects of AII on glomerular filtration dynamics were examined on a background of isoncotic plasma volume expansion. Prior plasma volume expansion affords certain advantages in the analysis of the effects of these agents on the filtration process. Firstly, the vascular resistance was low in the control condition and was therefore quite predictably responsive to vasoconstrictor agents. Secondly, prior volume expansion should have suppressed the renin system and prevented endogenous angiotensin generation. Thirdly, the high control renal plasma flow produced disequilibration of the effective filtration pressure in the control condition, which permitted determination of an accurate and unique value for glomerular permeability coefficient $\left(\mathrm{L}_{\mathrm{p}} \mathrm{A}\right)(16 a)$. Although Deen et al. have demonstrated that during plasma expansion in the Munich-Wistar rat, hypertension alone does not alter the $L_{p} A(36)$, the effects of Asn-1, Val-5 AII were first examined with subpressor quantities of this agent.

In a recent preliminary communication, Deen et al. (22) examined the effects of a variety of vasoconstrictors and vasodilators on glomerular function in the hy- 
TABLE IV

Pressures, Flows, Vascular Resistances, and Glomerular Permeability

\begin{tabular}{|c|c|c|c|c|c|c|c|}
\hline Rat & MAP & $P a$ & $P_{\boldsymbol{t}}$ & $\Delta P$ & sngfr & snff & rpf \\
\hline & $m m \mathrm{Hg}$ & $m m \mathrm{Hg}$ & $m m \mathrm{Hg}$ & $m m \mathrm{Hg}$ & $\begin{array}{c}n l / \min / \mathrm{g} \\
\text { kidney }\end{array}$ & & $\begin{array}{c}n l / \min / \mathrm{g} \\
\text { kidney }\end{array}$ \\
\hline \multicolumn{8}{|l|}{ Control plasma expansion } \\
\hline \multirow{2}{*}{30} & 130 & 58.5 & 18.7 & 39.8 & 70.8 & 0.16 & 402 \\
\hline & & \pm 4.8 & \pm 0.8 & \pm 5.1 & \pm 6.7 & & \pm 42 \\
\hline \multirow[t]{2}{*}{33} & 115 & 57.8 & 21.1 & 39.0 & 59.5 & 0.45 & 132 \\
\hline & & & \pm 1.4 & & \pm 3.1 & & \pm 7 \\
\hline \multirow[t]{2}{*}{34} & 113 & 66.9 & 25.7 & 39.4 & 61.1 & 0.31 & 197 \\
\hline & & \pm 3.7 & \pm 0.7 & \pm 3.6 & \pm 3.6 & & \pm 12 \\
\hline \multirow[t]{2}{*}{37} & 105 & 56.9 & 15.7 & 42.6 & 36.4 & 0.23 & 150 \\
\hline & & \pm 5.5 & \pm 1.0 & \pm 5.7 & \pm 2.3 & & \pm 10 \\
\hline \multirow[t]{2}{*}{38} & 132 & 64.4 & 20.3 & 43.9 & 48.1 & 0.27 & 178 \\
\hline & & & \pm 1.0 & & \pm 3.6 & & \pm 13 \\
\hline \multirow[t]{2}{*}{39} & 125 & 56.7 & 13.2 & 43.2 & 64.0 & 0.22 & 291 \\
\hline & & \pm 3.9 & \pm 0.2 & \pm 4.2 & \pm 4.8 & & \pm 22 \\
\hline \multirow[t]{2}{*}{ Overall mean } & 120 & 60.4 & 19.1 & 40.8 & 56.3 & 0.27 & 235 \\
\hline & \pm 4 & \pm 2.0 & \pm 1.8 & \pm 1.7 & \pm 2.8 & \pm 0.04 & \pm 22 \\
\hline \multicolumn{8}{|l|}{ Asp-1, Ile-5 A II } \\
\hline \multirow[t]{2}{*}{30} & 160 & 74.3 & 16.0 & 58.3 & 40.7 & 0.33 & 123 \\
\hline & & \pm 9.7 & \pm 0.3 & \pm 10.0 & \pm 8.7 & & \pm 26 \\
\hline \multirow[t]{2}{*}{33} & 150 & 62.4 & 14.7 & 48.3 & 40.0 & 0.31 & 129 \\
\hline & & & \pm 1.3 & & \pm 6.0 & & \pm 20 \\
\hline \multirow[t]{2}{*}{34} & 138 & 81.8 & 19.9 & 62.0 & 46.0 & 0.29 & 159 \\
\hline & & \pm 2.2 & \pm 3.4 & \pm 1.2 & \pm 3.7 & & \pm 13 \\
\hline \multirow[t]{2}{*}{37} & 110 & 57.6 & 10.2 & 47.2 & 23.3 & 0.31 & 75 \\
\hline & & \pm 0.6 & \pm 2.2 & \pm 1.8 & \pm 4.4 & & \pm 14 \\
\hline \multirow[t]{2}{*}{38} & 155 & 85.5 & 19.6 & 65.9 & 22.8 & 0.36 & 63 \\
\hline & & \pm 0.5 & \pm 2.1 & \pm 1.5 & \pm 2.7 & & \pm 8 \\
\hline \multirow[t]{2}{*}{39} & 144 & 68.9 & 14.2 & 54.7 & 29.9 & 0.31 & 96 \\
\hline & & \pm 2.9 & \pm 1.0 & \pm 2.7 & \pm 3.6 & & \pm 12 \\
\hline \multirow{2}{*}{ Overall mean } & 143 & 72.6 & 15.8 & 57.7 & 33.4 & 0.32 & 106 \\
\hline & \pm 7 & \pm 3.4 & \pm 1.5 & \pm 2.7 & \pm 2.5 & \pm 0.01 & \pm 8 \\
\hline$P$ valuef & $<0.001$ & $<0.001$ & $<0.025$ & $<0.001$ & $<0.001$ & $>0.3$ & $<0.001$ \\
\hline
\end{tabular}

* \pm SEM.

$\ddagger$ Compared to control condition.

$\S$ Minimum estimate at filtration pressure equilibrium.

dropenic rat. With larger pressor doses of AII, (40 ng/ $100 \mathrm{~g}$ body $\mathrm{wt} / \mathrm{min}$ ), the authors found a large increase in $\Delta P$ and a marked reduction in nephron plasma flow due to significant increases in both afferent and efferent arteriolar resistances. Filtration pressure equilibrium obtained in hydropenic rats both before and after AII. The large $(50 \%)$ decrease in nephron plasma flow could have obscured large reductions in $L_{p} A$ by maintaining filtration pressure equilibrium. Only minimum values for $\mathrm{L}_{\mathrm{p}} \mathrm{A}$ can be defined under conditions of filtration pressure equilibrium $(11,12,14)$. However, the findings of Deen et al. regarding the effects of AII on $\Delta P$, nephron plasma flow, and vascular resistances were similar to those observed in this study, in spite of the differing control states.
Under the conditions of control plasma expansion, a discrete value for $L_{p} A$ could be defined and was 0.063 and $0.061 \mathrm{nl} / \mathrm{s} / \mathrm{g}$ kidney $\mathrm{mm} \mathrm{Hg}$, significantly different from the value we have defined under disequilibrated conditions after hyperoncotic albumin expansion at somewhat higher values for both systemic oncotic pressure and nephron plasma flow (11).

After the infusion of approximately $5 \mathrm{ng} / 100 \mathrm{~g}$ body wt/min of Asn-1, Val-5 AII (subpressor quantities) and Asp-1, Ile-5 AII (pressor quantities) in group studies, the nephron plasma flow fell to $40-60 \%$ of control values. As an isolated event, this reduction should have decreased the efferent effective filtration pressure to a value approaching filtration pressure equilibrium (Fig. 3). However, the $\operatorname{EFP}_{z}$ rose from 9.5 to 16.0 and 
before and during the Infusion of Asp-1, Ile-5 Angiotensin II

\begin{tabular}{|c|c|c|c|c|c|c|c|c|}
\hline rbf & $\mathbf{A R}$ & ER & $\mathbf{H P B}$ & $\pi_{4}$ & $\pi_{B}$ & $\overline{\mathrm{EFP}}$ & $\mathbf{L}_{\mathrm{p}} \mathbf{A}$ & $\mathbf{E F P}_{B}$ \\
\hline$\underset{k i d n e y}{n l / m i n / g}$ & $\begin{array}{c}\times 100 d y n \\
s / c^{b}\end{array}$ & $\begin{array}{l}\times 100 d y n \\
\text { s/cms }\end{array}$ & $m m H_{g}$ & $m m \mathrm{Hg}$ & $m m \mathrm{Hg}$ & $m m \mathrm{Hg}$ & $\begin{array}{c}n l / s / g \\
k i d n e y / \\
m m H_{g}\end{array}$ & $m m \mathrm{Hg}$ \\
\hline 776 & 7.4 & 4.2 & 21.8 & 22.6 & 29.4 & 13.9 & 0.076 & 10.4 \\
\hline \pm 73 & & & \pm 1.4 & & & & $\pm 0.004^{*}$ & \\
\hline 234 & 19.5 & 19.0 & 16.3 & 17.6 & 43.9 & 8.6 & $0.102 \S$ & -4.9 \\
\hline \pm 12 & & & \pm 1.8 & & & & \pm 0.003 & \\
\hline 339 & 10.8 & 10.7 & 29.6 & 13.1 & 22.6 & 22.1 & 0.046 & 16.8 \\
\hline \pm 20 & & & \pm 0.3 & & & & \pm 0.006 & \\
\hline 273 & 14.1 & 12.9 & 18.7 & 23.7 & 35.2 & 13.2 & 0.042 & 7.4 \\
\hline \pm 18 & & & \pm 0.9 & & & & \pm 0.002 & \\
\hline 336 & 16.0 & 9.7 & 29.3 & 20.0 & 32.5 & 17.9 & 0.045 & 11.4 \\
\hline \pm 25 & & & \pm 0.6 & & & & \pm 0.002 & \\
\hline 560 & 9.7 & 6.3 & 17.7 & 19.5 & 28.2 & 19.6 & 0.054 & 15.0 \\
\hline \pm 42 & & & \pm 1.4 & & & & \pm 0.001 & \\
\hline 425 & 12.9 & 10.5 & 22.2 & 19.4 & 32.0 & 15.9 & 0.061 & 9.4 \\
\hline \pm 39 & \pm 1.8 & \pm 2.1 & \pm 2.4 & \pm 1.5 & \pm 2.9 & \pm 2.0 & \pm 0.001 & \pm 3.1 \\
\hline 212 & 32.2 & 28.8 & 12.8 & 16.2 & 29.4 & 36.4 & 0.018 & 28.9 \\
\hline \pm 45 & & & \pm 0.1 & & & & $\pm 0.005^{*}$ & \\
\hline 226 & 30.9 & 19.5 & 16.9 & 15.7 & 27.3 & 27.5 & 0.024 & 21.0 \\
\hline \pm 34 & & & \pm 0.2 & & & & \pm 0.002 & \\
\hline 278 & 16.1 & 21.3 & 19.8 & 15.7 & 26.5 & 41.6 & 0.019 & 35.5 \\
\hline \pm 22 & & & \pm 2.0 & & & & \pm 0.001 & \\
\hline 144 & 29.0 & 30.8 & 11.0 & 20.0 & 35.7 & 19.8 & 0.020 & 11.5 \\
\hline \pm 27 & & & \pm 1.7 & & & & \pm 0.003 & \\
\hline 122 & 45.4 & 43.8 & 31.1 & 18.0 & 35.7 & 40.4 & 0.009 & 30.2 \\
\hline \pm 15 & & & \pm 0.6 & & & & \pm 0.001 & \\
\hline 189 & 31.7 & 28.0 & 13.1 & 14.8 & 25.9 & 35.1 & 0.014 & 28.8 \\
\hline \pm 24 & & & \pm 2.1 & & & & \pm 0.001 & \\
\hline 193 & 30.9 & 28.7 & 17.4 & 16.7 & 30.1 & 33.5 & 0.017 & 26.0 \\
\hline \pm 14 & \pm 3.8 & \pm 3.5 & \pm 3.0 & \pm 0.8 & \pm 1.8 & \pm 3.4 & \pm 0.002 & \pm 3.5 \\
\hline$<0.001$ & $<0.001$ & $<0.001$ & $<0.05$ & $>0.05$ & $>0.5$ & $<0.001$ & $<0.001$ & $<0.001$ \\
\hline
\end{tabular}

$13.5 \mathrm{~mm} \mathrm{Hg}$, respectively, in group studies and higher in paired studies. The only other factor which could have prevented a reduction in $\mathrm{EFP}_{\boldsymbol{s}}$ with reduced plasma flow was a major decrease in the glomerular permeability coefficient $\left(L_{p} A\right)$. The $L_{p} A$ in fact fell to lower, very similar values in both AII groups with $5 \mathrm{ng} / 100 \mathrm{~g}$ body $\mathrm{wt} / \mathrm{min}$. This finding was also substantiated in paired studies with Asp-1, Ile-5 AII. Both the reduction in nephron plasma flow and $L_{p} A$ acted to reduce nephron filtration rate.

As a result of the resistance alterations, $P_{a}$ increased. Also, $P_{t}$ decreased, possibly related to the reductions in nephron plasma flow and sngfr. The net effect of the two events was an increase in $\Delta P$, which modified the effect of AII on sngfr by producing a positive effect on the glomerular filtration rate. Therefore, the reduction in $\mathrm{L}_{\mathrm{p}} \mathrm{A}$ was the decisive factor mediating the decrease in sngfr with both forms of AII. If $L_{p} A$ had not fallen, sngfr would have remained constant, since the increase in $\Delta P$ would have effectively neutralized the effect of decreased nephron plasma flow on sngfr (Fig. 3). These findings are then compatible with the qualitative findings of Hornych et al. (9) of reduced glomerular capillary radius after subpressor doses of Asn-1, Val-5 AII.

Prior studies do suggest that Asn-1, Val-5 AII differs from endogenous rat AII in quantitative potency as a vasoconstrictor, but no significant qualitative differences in specificity of effect have been demonstrated (23). Studies with Asp-1, Ile-5 AII revealed that lesser quantities of this compound were required to produce 
hypertension as a result of peripheral vasoconstriction. In the low-dose group, $2.5 \mathrm{ng} / 100 \mathrm{~g}$ body $\mathrm{wt} / \mathrm{min}$ was the maximum amount of this agent infused, approximately one-half the dose of Asn-1, Val-5 AII used. Therefore, this agent appears more potent per nanogram as a peripheral vasoconstrictor (16), but with minimum pressor doses has little effect on both the glomerular capillary and afferent and efferent resistances.

Although similar total doses of both forms of AII were required to obtain a reduction in $\mathrm{L}_{\mathrm{p}} \mathrm{A}$, the endogenously produced AII had a greater peripheral vascular effect than the nonbiologically synthesized preparation. This greater effect has been previously observed and attributed to more efficient degradation of this form of AII by tissue aminopeptidases as a result of the differing $\mathrm{NH}_{2}$-terminal amino acid substitution (37). However, since the glomerular capillary effects were nearly identical at the same dose of both agents, the kinetics of AII action and degradation must be similar in this vascular bed. The Asn-1, Val-5 AII compound produced a reduction in nephron plasma flow and increase in vascular resistance while there was no evidence of significant effect upon peripheral vessels, as evidenced by the lack of a significantly increased systemic blood pressure.

The major finding of this study is the reduction in $L_{p} A$ with AII. Recent studies have suggested at least quantitative if not qualitative differences in the adrenal cortical and peripheral effects of AII $(8,38)$, although possibly mediated by AII action upon contractile cells. Since no smooth muscle cells are located in or around the glomerular capillary $(35,39)$, a separate effector cell that reduces either local permeability or effective surface area must be postulated. No direct evidence has been provided that elucidates either the effector cell or the specific mechanism for the AII-mediated reduction in gomerular permeability coefficient. Either a reduction in local permeability of the glomerular membrane or a decrease in capillary surface area or both could explain the lower $L_{p} A$.

If all of the decrease in $L_{p} A$ was a result of reduced radius, the changes would be directly proportional ( $A=$ $2 \pi r l)$. Measurements of capillary pressure in the same glomerulus performed in this laboratory have suggested that the decrement in $P_{G}$ along the length of the glomerular capillary $\left(\Delta P_{G}\right)$ is at most $1-2 \mathrm{~mm} \mathrm{Hg}$ in the hydropenic state. If the observed decrease in $L_{p} A$ were entirely due to reduced capillary radius, then, utilizing Poiseuillian relationships, the $\Delta P_{G}$ should have increased considerably to $16-32 \mathrm{~mm} \mathrm{Hg}$. This change should have resulted in a marked increase in variance in $P_{G}$ after AII; however, no such increase was observed in this study. It is recognized that these estimates are only approximations of the real physiologic events and are therefore subject to inaccuracies. It remains quite likely that the observed reductions in $\mathrm{L}_{\mathrm{p}} \mathrm{A}$ may have been mediated, at least partially, by decreases in local capillary permeability $\left(L_{p}\right)$.

That changes in $L_{p} A$ correlated positively with increased renal vascular resistance (Fig. 4) suggests only that the effect of AII upon renal vascular smooth muscle coincided with the effect on $L_{p} A$. Even if the $L_{p} A$ effects were due to reduced capillary radius alone, the increased resistance would not contribute significantly to the increase in total renal vascular resistance $(10-12 \%$ of total) due to the very low control capillary resistance.

The biologic relevance of the present findings remains somewhat ill-defined. Certainly the demonstration of an AII effect on $L_{p} A$ may be added to the known effects on vascular smooth muscle and aldosterone release from the adrenal. However, have the effective biologic levels of AII been achieved in the present study? It has been possible to delineate the specific range of values for interstitial AII concentration from the evaluation of renal lymph AII levels by radioimmunoassay (40). The AII levels after aortic constriction were well above the intravascular concentration produced by the infusion of $5 \mathrm{ng} / 100 \mathrm{~g}$ body $\mathrm{wt} / \mathrm{min}$ of AII. It is therefore possible that much higher levels of endogenously generated AII may be achieved at the effector site for $\mathrm{L}_{\mathrm{p}} \mathrm{A}$ reduction under conditions of maximum AII generation.

We have evaluated the change in $L_{p} A$ under conditions of high nephron plasma flow during plasma expansion because accurate calculations can be performed without attainment of filtration pressure equilibrium. In the hydropenic condition, at filtration pressure equilibrium, the effect of this quantitative reduction in $\mathrm{L}_{\mathrm{p}} \mathrm{A}$ upon sngfr would be diminished, due to both the corresponding decrease in nephron plasma flow and increased $\Delta P$. At filtration pressure equilibrium, if proportional reductions in plasma flow are similar, the dominant factor acting to reduce sngfr should be the reduction in plasma flow. The reduction in $\mathrm{L}_{\mathrm{p}} \mathrm{A}$ would contribute to a reduction in sngfr if $\mathrm{L}_{\mathrm{p}} \mathrm{A}$ fell to $\sim 0.02$ $\mathrm{nl} / \mathrm{s} / \mathrm{g}$ kidney $/ \mathrm{mm} \mathrm{Hg}$ and $\Delta P$ and nephron plasma flow changed in similar proportions to those observed in the plasma-expanded state. It must be assumed that the much higher potential interstitial AII concentrations generated endogenously could affect larger $L_{p} A$ reductions.

One cannot directly apply the results obtained after the intravenous infusion of AII to the question of a potential intrarenal role for this substance. Preceding studies have provided indirect evidence that the mesangial cell might provide the site of AII receptor and the effector cell mediating the reduction in $\mathrm{L}_{p} A(9,10)$. The mesangial cell as part of the juxtaglomerular complex is contiguous or directly in contact with the juxtaglo- 
merular cells (41-43) and the capillary flow $(44,45)$. Because of the proximity of the two cell types, local generation and release of AII could produce even greater local $L_{p} A$ alterations than those presently observed if interstitial concentrations were very high. Estimates of renin concentration in single juxtaglomerular units by Thurau have been exceedingly high (46), and the interstitial (lymph) concentrations of AII estimated by Bailie et al. (40) have also suggested equally impressive local AII generation and release. Because of the close contiguity of the juxtaglomerular cell and capillarymesangium, it remains possible that the effects of AII on $L_{p} A$ may be considerable, with minimal effects on the smooth muscle of afferent or efferent vessels, leading to minimal obligatory alterations in nephron plasma flow.

The last and most speculative aspect of this discussion relates to this effect of AII on $\mathrm{L}_{\mathrm{p}} \mathrm{A}$ and the tubuloglomerular feedback control of nephron filtration rate. Thurau and Schnermann and their associates have proposed AII as a potential mediator for the observed reciprocal relation between either distal tubular $\mathrm{NaCl}$ delivery or reabsorptive rate and the filtration rate in the same nephron $(31,47)$. Alteration in hydrostatic pressures in the glomerular capillary has proven inadequate as a single mechanism explaining the efferent limb of this tubulo-glomerular feedback system $(7,33)$. We have suggested that if such a relation exists, it must be mediated through changes in nephron plasma flow (17). The present findings of an AII effect upon $L_{p} A$ raise the question whether this mechanism could explain, in part, the observed reciprocal relationship. Thurau and Schnermann, in early studies, suggested as one of several mechanisms a specific AII effect on the glomerular capillary (47). However, we would reiterate that there are severe constraints on the expression of reduced $L_{p} A$ in the hydropenic rat at filtration pressure equilibrium. This statement is especially true with reductions in nephron plasma flow and increased $\Delta P$. Because of the large decrease in nephron plasma flow, large reductions in $L_{p} A$ will be tolerated by the system and not lead to disequilibration of the effective filtration pressure. In addition, the increase in $\Delta P$ will substantially neutralize the effect of both decreased nephron plasma flow and $L_{p} A$ upon nephron filtration rate.

In summary, for reduced $L_{p} A$ to produce a decrease in nephron filtration rate, the $\mathrm{L}_{p} \mathrm{~A}$ effects must predominate over the effects on both nephron plasma flow and $\Delta P$ before disequilibration of the effective filtration pressure and decrease in nephron filtration rate will result. Therefore, a specific biologic role for AII upon $\mathrm{L}_{\mathrm{p}} \mathrm{A}$ in the modification of sngfr in the hydropenic animal remains speculative at this time. A third biologic effect for AII has been described in this study, an effect of AII upon the permeability coefficient of the glo- merular capillary $\left(L_{p} A\right)$. The effect of AII appears to be a mechanism separate and distinct from those previously described on vascular smooth muscle and upon the adrenal cortex.

\section{ACKNOWLEDGMENTS}

We are grateful to Dr. F. Merlin Bumpus, Cleveland Clinic Research Foundation, Cleveland, Ohio, for providing a highly purified form of Asp-1, Ile-5 AII. Our appreciation is extended for the excellent secretarial support provided by Ms. Ann Chavez.

Studies were supported through grants from the National Institutes of Health (HL-14914), the Southern California Kidney Foundation, and the Veterans Administration.

\section{REFERENCES}

1. Vane, J. R. 1969. The release and fate of vasoactive hormones in the circulation. Br. J. Pharmacol. 35: 209-242.

2. Somlyo, A. V., and A. P. Somlyo. 1966. Effect of angiotensin and beta-adrenergic stimulation on venous smooth muscle. Am. Heart J. 71 : 568-570.

3. Helmer, O. M. 1964. Action of natural angiotensin II and synthetic analogues on strips of rabbit aorta. $\mathrm{Am}$. J. Physiol. 207 : 368-370.

4. Gross, F. 1971. Angiotensin. In Pharmacology of Naturally Occurring Polypeptides and Lipid-Soluble Acids. J. M. Walker, editor. Oxford, Pergamon Press, Ltd., Oxford, England. I : 73-286.

5. Regoli, D., and R. Gauthier. 1971. Site of action of angiotensin and other vasoconstrictors on the kidney. Can. J. Physiol. Pharmacol. 49: 608-612.

6. Krahé, P., K. G. Hofbauer, and F. Gross. 1971. Effects of angiotensin infusion on the isolated rabbit kidney. Proc. Soc. Exp. Biol. Med. 137: 1324-1327.

7. Peytremann, A., W. E. Nicholson, R. P. Brown, G. W. Liddle, and J. G. Hardman. 1973. Comparative effects angiotensin and ACTH on cyclic AMP and steroidogenesis in isolated bovine adrenal cells. J. Clin. Invest. 52: 835-842.

8. Williams, G. H., L. M. McDonald, M. C. Raux, and N. K. Hollenberg. 1974. Evidence for different angiotensin II receptors in rat adrenal glomerulosa and rabbit vascular smooth muscle cells. Studies with competitive antagonists. Circ. Res. 34: 384-390.

9. Hornych, H., M. Beaufils, and G. Richet. 1972. The effect of exogenous angiotensin on superficial and deep glomeruli in the rat kidney. Kidney Int. 2: 336-343.

10. Sraer, J. D., J. Sraer, R. Ardaillou, and O. Mimoune. 1974. Evidence for renal glomerular receptors for angiotensin II. Kidney Int. 6: 241-246.

11. Blantz, R. C., F. C. Rector, Jr., and D. W. Seldin. 1974. Effect of hyperoncotic albumin expansion on glomerular ultrafilteration in the rat. Kidney Int. 6: 209221.

12. Blantz, R. C. 1974. Effect of mannitol on glomerular ultrafilteration in the hydropenic rat. J. Clin. Invest. $54:$ : 1135-1143.

13. Nakayama, T., T. Nakajima, and H. Sokabe. 1972. Comparative studies on angiotensins. II. Structure of rat angiotensin and its identification by DNS-Method. Chem. Pharm. Bull. (Tokyo). 20: 1579-1581.

14. Blantz, R. C. 1975. The mechanism of acute renal failure after uranyl nitrate. J. Clin. Invest. 55: 621-635. 
15. Brenner, B. M., J. L. Troy, T. M. Daugharty, W. M. Deen, and C. R. Robertson. 1972. Dynamics of glomerular ultrafiltration in the rat. II. Plasma-flow dependence of G.F.R. Am. J. Physiol. 223: 1184-1190.

16. Nakajima, T., S. Sakakibara, A. Sakuma, and H. Sokabe. 1973. Specific pressor activity of Angiotensins I and II. Jpn. J. Pharmacol. 23 : 591-593.

16a. Blantz, R. C., K. Konnen, and B. J. Tucker. 1975. Glomerular filtration response to elevated ureteral pressure in both the hydropenic and plasma expanded rat. Circ. Res. 37: 819-829.

17. Blantz, R. C., A. H. Israelit, F. C. Rector, Jr., and D. W. Seldin. 1972. Relation of distal tubular $\mathrm{NaCl}$ delivery and glomerular hydrostatis pressure. Kidney Int. 2: 22-23.

18. Lowry, O. H., N. J. Rosebrough, A. L. Farr, and R. J. Randall. 1951. Protein measurement with the Folin phenol reagent. J. Biol. Chem. 193: 265-275.

19. Todd, J. C., and A. Sanford. 1969. Clinical Diagnosis by Laboratory Methods. W. B. Saunders Company, Philadelphia. 14th edition. 47-48.

20. Landis, E. M., and J. R. Pappenheimer. 1963. Exchange of substances through the capillary walls. Handb. Physiol. Section 2 Circulation. 2: 961-1034.

21. Bliss, C. I. 1970. Statistics in Biology. McGraw-Hill Book Company, New York. 186-205.

22. Deen, W. M., B. D. Myers, J. L. Troy, and B. M. Brenner. 1974. Effects of vasoactive substances on preglomerular, glomerular, and postglomerular microcirculation. American Society of Nephrology. 7: 21. (Abstr.)

23. Regoli, D., W. K. Park, and F. Rioux. 1973. Pharmacology of Angiotensin. Pharmacol. Rev. 26: 69-123.

24. Schwyzer, R., B. Iselin, H. Kappeler, B. Riniker, W. Rittel, and H. Zuber. 1958. Synthese hochwirksamer Oktapetide mit der vermutlichen Aminosäuresequenz des noch unbekanten Hypertensins II aus Rinderserum (Vals-Hypertensin II und Vals-Hypertensin II-Asp- $\beta$ amid). Helv. Chim. Acta. 41 : 1287-1295.

25. Schwyler, R., and H: Turrian. 1960. The chemistry and pharmacology of angiotensin. Vitam. Horm. 18: 237288.

26. Davis, J. O. 1971. The renin-angiontensin system in the control of aldosterone secretion. In Kidney Hormones. J. W. Fisher, editor. Academic Press, Inc., Ltd. London. 173-205.

27. Schmid, H. E., Jr. 1962. Renin, a physiologic regulator of renal hemodynamics? Circ. Res. 11: 185-193.

28. Thurau, K. 1964. Renal hemodynamics. Am. J. Med. 36 : 698-719.

29. McGiff, J. C. 1968. Tissue hormones: Angiotensin, bradykinin and the regulation of regional blood flows. Med. Clin. North Am. 52: 263-281.

30. Britton, K. E. 1968. Renin and renal autoregulation. Lancet. 2 : 329-333.

31. Schnermann, J., F. S. Wright, J. M. Davis, W. V. Stackelberg, and G. Grill. 1970. Regulation of super- ficial nephron filtration rate by tubulo-glomerular feedback. Pflügers Arch. Eur. J. Physiol. 318: 147-175.

32. Navar, L. G., T. J. Burke, R. R. Robinson, and J. R. Clapp. 1974. Distal tubular feedback in the autoregulation of single nephron glomerular filtration rate. J. Clin. Invest. 53: 516-525.

33. Schnermann, J., A. E. G. Persson, and B. Ågerup. 1973. Tubuloglomerular feedback. Nonlinear relation between glomerular hydrostatic pressure and loop of Henle perfusion rate. J. Clin. Invest. 52: 862-869.

34. Wright, F. S., and J. Schnermann. 1974. Interference with feedback control of glomerular filtration rate by furosemide, triflocin, and cyanide. J. Clin. Invest. 5.3: 1695-1708.

35. Huhn, D., J. W. Steiner, and H. Z. Movat. 1962. Die Feinstruktur des Mesangiums im Nierenglomerulum von Hund und Maus. Z. Zellforsch. Mikrosk. Anat. 56: 213230.

36. Deen, W. M., J. L. Troy, C. R. Robertson, and B. M. Brenner. 1973. Dynamics of glomerular ultrafiltration in the rat. IV. Determination of the ultrafiltration coefficient. J. Clin. Invest. 52: 1500-1508.

37. Regoli, D. F. Rioux, W. K. Park, and C. Choi. 1974. Role of N-terminal amino acid for the biological activity of angiotensin and inhibitory analogues. Can. J. Physiol. Pharmacol. 52: 39-49.

38. Steele, J. M., Jr., and J. Lowenstein. 1974. Differential effects of an Angiotensin II analogue on pressor and adrenal receptors in the rabbit. Circ. Res. 35: 592-600.

39. Latta, H., and A. B. Maunsbach. 1962. Relations of the centrolobular region of the glomerulus to the juxtaglomerular apparatus. J. Ultrastruct. Res. 6: 562-578.

40. Bailie, M. D., F. C. Rector, Jr., and D. W. Seldin. 1971 Angiotensin II in arterial and renal venous plasma and renal lymph in the dog. J. Clin. Invest. 50: 119-126.

41. Hatt, P.-Y., and G. Berjal. 1971. Le mésangium glomérulaire dans l'hypertension artérielle expérmentale du Rat. Etude en microscopie électronique. J. Urol Nephrol. 71: 286-294.

42. Barajas, L., and H. Latta. 1963. The juxtaglomerular apparatus in adrenalectomized rats. Light and electron microscope observations. Lab. Invest. 12: 1046-1059.

43. Michielsen, P. 1965. La fonction du mésangium. J. Urol. Nephrol. 71: 283-285.

44. Vernier, R. L., S. M. Mauer, A. J. Fish, and A. F. Michael. 1971. Les cellules mésangiale dans les glomérulonephrites. Actual. Nephrol Hôp. Necker. 37-51.

45. Yamada, E. 1955. The fine structure of the renal glomerulus of the mouse. J. Biophys. Biochem. Cytol. 1: $551-556$, and plates $134-140$.

46. Thurau, K. 1974. JGA renin activity. Proc. Int. Congr. Nephrol. 2: 183-192.

47. Thurau, K., and J. Schnermann. 1965. Die Natriumkonzentration an den Macula densa-Zellen als regulierender Faktor für das Glomerulumfiltrat (Mikropunktionversuche). Klin. Wochenschr. 43: 410-413. 